\title{
BEAHAVIOUR OF REINFORCED CONCRETE BEAMS MADE OUT OF RECYCLED CONCRETE
}

\author{
Mohamed H. Matthana \\ Structural Engineering Department, Faculty of Engineering, \\ EL-Mansoura University, EL-Mansoura, EGYPT.
}

\begin{abstract}
Concrete is the most widely used construction material. Waste concrete represents an unavoidable product of concrete industry. It is produced because of the demolition of concrete structures, rejected concrete, leftover fresh batches, unwanted elements in pre-cast factories, etc. Waste concrete is usually discarded in landfills causing very serious environmental problems. As the interest in recycling waste materials is, nowadays, getting an increasing worldwide attention, there is an environmental incentive for recycling waste concrete with the other types of recycling. In a previous paper by the author et. al., the properties of recycled concrete have been given a detailed study. The present investigation is aimed at understanding the effect of using recycled concrete on the behaviour of reinforced concrete beams. Waste concrete with no information about its previous mix properties and original strength and quality is used. The waste concrete is manually crushed and then tested for grading, bulk unit weight, and water absorption. Concrete specimens; cubes, beams, and cylinders from mixes made out of crushed concrete as a part of coarse aggregate are prepared and then tested for the uniaxial compression, splitting tension, and flexural strengths. The uni-axial stress-strain behaviour and the modulus of elasticity are also obtained. A total of eighteen reinforced concrete beams have been casted and tested to study the behaviour of beams made out of recycled concrete. This number of beam specimens is divided into six groups. Three groups of beams are tested for shear loading while the other three groups were aimed for flexural loading. Both of the flexural and shear groups of beams consisted of three categories each of three beams. The first category of beams was made out of normal concrete with normal coarse aggregate from gravel while the other two categories are made out of recycled concrete with coarse aggregate from crushed concrete. The latter two categories had two various ratios of crushed concrete as a part of the coarse aggregate. The study brings out the important results that; the use of recycled concrete reduces both the load carrying capacity and the stiffness of beams while the design equations, given by various codes, for normal concrete may be applicable for reinforced beams made out of recycled concrete without great loss of accuracy.
\end{abstract}

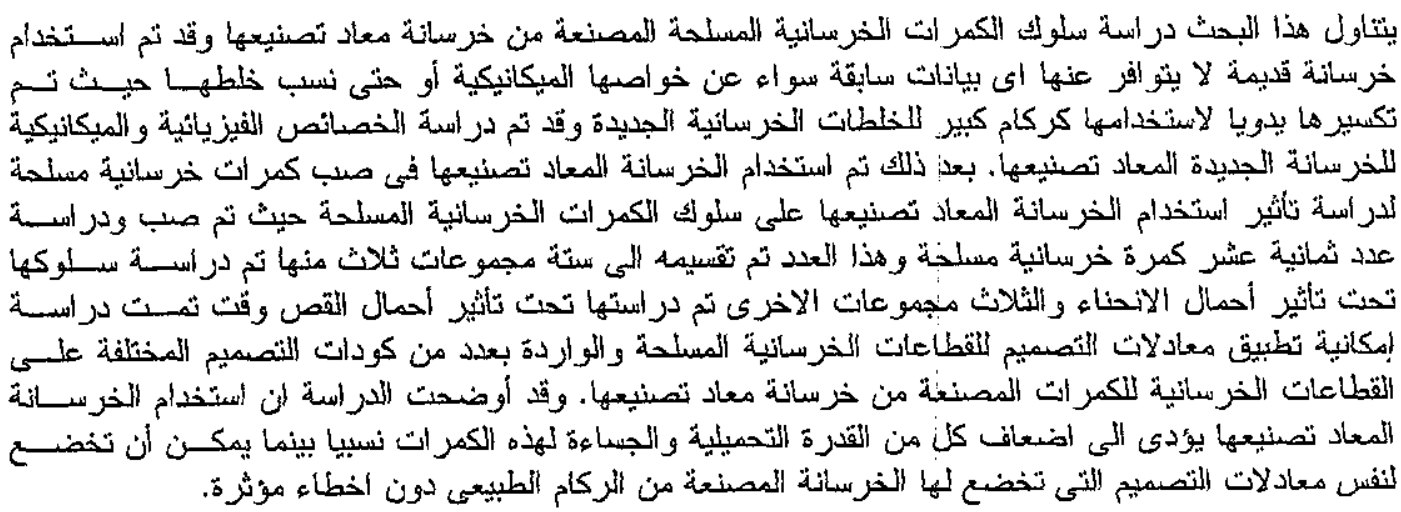

Keywords : Reinforced Concrete; Beams; Crushed Concrete; Recycled Beams \& Recycled Concrete. 


\section{INTRODUCTION}

With the great development in all activities allover the world, the mass of waste materials has been increased to the extent that it is now representing a very serious environmental problem as it limits the right of mankind to live in a clean and healthy environment. Therefore, the interest in recycling of waste materials is, nowadays, getting an increasing worldwide attention. As with the other types of recycling, there is an environmental incentive for recycling waste concrete. Concrete is the most widely used construction material. The world consumption of concrete is approximately 4.5 billion tons a year (Mehta, 1986). Waste concrete is produced because of the demolition of structures due to different reasons such as earthquake, fire, explosion, rejected concrete and leftover fresh batches. It has been estimated by the Environmental Resources Ltd., (1980), that, every year, approximately 130 million tons of concrete are discarded in the European Economic Community, the United Stated and Japan. It has been further estimated that, these figures will increase approximately threefold by the year 2000, (Salem et. al., 1998). In many places where there is a short supply in quality aggregates, the need to recycle waste concrete takes an economical point of view. In such places, importing aggregates can be quite expensive because of the transportation costs. In view of the environmental and economical benefits, the concept of recycling waste concrete and reusing it in another form has gained momentum in the last four decades. Frondistou-Yannas, (1977), Rassheeduzzafar et. al., (1984), Mulheron et. al., (1988), and Tavakoli et. al., (1996), have carried out investigations to study the properties of both recycled aggregate and recycled concrete. Matthana, M. H. \& Tahwia, A. M., (2002), carried out a detailed experimental investigation to study the strength properties of recycled concrete. The effect of using recycled concrete on the behaviour of reinforced concrete members has not get enough interest. The present study is aimed at understanding the effect of using recycled concrete on the behaviour of reinforced concrete beams.

\section{EXPERIMENTAL PROGRAM LAYOUT}

\section{Materials}

Waste concrete used for experimentation in this study is obtained from previously tested and crushed concrete cubes available in the laboratory of concrete structures, Faculty of Engineering, El-Mansoura University, Egypt. The waste cubes are taken randomly without any information about its previous properties. In other wards, the original strength and mix proportions of those waste cubes are unknown. The waste cubes are manually crushed and sieved through the $38-\mathrm{mm}$ sieve size and the same sieve is used for gravel. Crushed concrete is then mixed in various mix proportions with the other coarse aggregate from gravel. Fine aggregate from sand is used. The grading of aggregates from gravel, crushed concrete and sand is shown along with the limits of the ES-1109, in Fig. (1) \& Fig. (2), respectively, while, the physical properties of both gravel and coarse aggregate from crushed concrete are summarized in Table (1). The same ordinary Portland cement is used along with potable water in all mixes. Before mixing, the coarse aggregate, from both gravel and crushed concrete, was well washed to avoid the existence of excess of fines in crushed concrete and also to utilize the difference in the water absorption of the two materials. Three mix proportions are considered. The $100 \%$ coarse aggregate from gravel is considered as the control mix in the control beam-groups (group A \& group D).

The coarse aggregate from crushed concrete is added with ratios $50 \%$, and $100 \%$ of the total weight of coarse aggregate. All mix proportions are by weight. Mechanical mixing and mechanical compacting in moulds using table vibrator is maintained for all mixes. Various types of moulds; cubes, cylinders and beams are used for casting various specimens. All moulds are removed after 24 hours from casting and all specimens are kept in water for 28 days for curing. The Egyptian code and standards [2-6] are followed. The details of various concrete mixes of both normal and recycled concrete are summarized in Table (2). Hardened concrete made out of the three mix proportions are tested for, the compressive strength, splitting and flexural tensile strengths and the stress-strain behaviour. The modulus of elasticity is also measured. The compressive strength is studied through $15 \times 15 \times 15 \mathrm{~cm}$ cubes, while the $15 \times 30 \mathrm{~cm}$ cylinders are used for measuring the splitting tensile strength, the value of Young's modulus, and for predicting the stress-strain behaviour. The standard compresso-meter is used to measure the values of vertical strains of concrete cylinders. The flexural strength is studied through $10 \times 10 \times 70 \mathrm{~cm}$ beams. The final test results of the used materials are given in Table (3), while Fig. (3) shows the stress strain behaviour of recycled concrete with various mix proportions. The values of compressive strength, splitting, and flexural tensile strengths and the value of the modulus of elasticity are normalized as percentage ratios to those of the control mix (mix No. 1 of $100 \%$ coarse aggregate from gravel). The reported values of the modulus of elasticity are the secant values at $25 \%$ of the ultimate stress of each mix. More details of physical and mechanical properties of various types of recycled concrete mixes and their constituents were given in a previous paper by Matthana \& Tahwia, 2002. High grade steel 
(36/52) is used in both bottom and top reinforcement of all beams, while the normal mild steel $(24 / 35)$ is used for web reinforcement in flexural groups.

\section{Details of the Test Specimens}

The test specimens, considered in the present study, include 18 simply supported reinforced concrete beams divided into six groups each of three specimens. Three of the beam groups with three various recycled concrete mixes are maintained for flexural loading while the other three are maintained for shear loading. All specimens have the same cross section of $12 \times 20 \mathrm{~cm}^{2}$, the same overall span of $185.0 \mathrm{~cm}$ and the same effective span of $160.0 \mathrm{~cm}$. All beams are provided with a main (bottom) reinforcement of two-bars of $16-\mathrm{mm}$ diameter and top reinforcement of two bars of $10-\mathrm{mm}$ diameter. The beams of the flexural groups are provided with web reinforcement of 6-mm diameter stirrups arranged at spacing of $10 \mathrm{~cm}$. The details of test specimens considered in the experimental program are given in Table (4), while the configurations of these specimens are shown in Fig. (4). Wooden moulds are used for casting beam specimens. Mechanical mixing and mechanical compacting in beam moulds using table vibrator is maintained for all beams. All moulds are removed after 24 hours from casting and all beam-specimens are kept under damp jute bags for 28 days for curing.

\section{Test Procedure}

The reinforced concrete beams were simply supported and tested in a loading frame under twopoint compressive loading. Special bearing assemblies (rollers, bearing blocks, etc.) were designed to facilitate the application of loads to the test specimens. Dial gauges were mounted at the bottom face of beams at mid-span and under the loading points. Each beam specimen was instrumented with two electrical strain gauges; one is fixed on one of the main longitudinal reinforcing bars at mid span. In the flexural groups, the second strain gauge is fixed on an end stirrup while it is fixed near the end of one of the bottom steel bars in the shear groups; Fig. (4). The configurations of the loading system and the experimental set-up are shown schematically in Fig. (4), while Plate (1) shows the photograph of the experimental set-up at testing. At the beginning of loading, small fraction of the expected failure load of various specimens was applied slowly and then removed in order to exercise the deformation instruments. Load is then applied in small increments and all the deformation readings are recorded at the end of each load increment. The initiation and propagation of cracks were marked and the mode of failure was noted after final collapse.

\section{RESULTS, DISCUSSIONS, AND MAJOR OBSERVATIONS}

Behaviour of Beams with Various Recycled Concrete Mixes under Flexural Loading

Plate (2) shows the cracking patterns of different groups of reinforced concrete beams with various recycled concrete mixes under flexural loading while the experimental test results are summarized in Table (5). As shown in Plate (2), the cracking patterns of various beam groups are nearly similar while the results presented in Table (5) show that, the beams of each group exhibit different values of both cracking and ultimate loads and the central deflection is also different. As presented in Table (5), the control beam group; group A, had the first crack at a load of 2.571 ton which is about $26.5 \%$ of its ultimate load in the form of flexural crack while the beam groups B \& C with crushed concrete of $50 \%$ and $100 \%$, respectively, of the coarse aggregate of the recycled concrete mix experienced their first cracks at loads of 2.351 ton \& 2.072 ton which are about $25.7-25 \%$ of the ultimate load of each group and both of them had also the form of flexural crack. With the increase in the applied flexural load, each beam group exhibited another mode of cracking in the shape of shear cracks. The shear cracks initiated in the control beam; group A, at a load of 7.143 ton, which is about $74 \%$ of the ultimate load of the same group while a similar mode of cracking started in the other two groups; group B \& group C with crushed concrete of $50 \%$ and $100 \%$, respectively, of the coarse aggregate of the recycled concrete mix, at 6.269 ton $\& 5.524$ ton which are about $69 \% \& 67 \%$ of the ultimate loads of the two beam groups, respectively. Finally, the control beam failed, in the mode of flexural failure, at a load of 9.714 ton while both groups $\mathrm{B} \& \mathrm{C}$ exhibited the same flexural failure at lower values of loads; specifically at 9.143 ton for group B with $50 \%$ crushed concrete as a coarse aggregate and 8.286 ton for group $\mathrm{C}$ which has a recycled concrete mix with $100 \%$ crushed concrete as the coarse aggregate. It is now clear that the reinforced concrete, beams made out of recycled concrete mixes exhibit lower performance than those made out of normal concrete having gravel as the coarse aggregate. In other words, the use of recycled concrete mixes with crushed concrete as a part of coarse aggregate leads to reinforced concrete beams with lower values of both cracking and ultimate loads and the decrease of both loads increases with an increase in the percentage of crushed concrete in the coarse aggregate of the concrete mix.

Figure (5) shows the variation in the central deflection of various beam groups with the applied flexural load. As shown in the figure, the variations in the central deflections, with the applied load, follow nonlinear paths which are similar for all beam 
groups. The control beam, with normal concrete made out of gravel as the coarse aggregate, exhibited the least values of central deflection while the beams of group C with concrete mix of $100 \%$ crushed concrete as the coarse aggregate exhibited the maximum. When crushed concrete is added as $50 \%$ of the coarse aggregate in the recycled concrete mix; group $\mathrm{B}$, the reinforced concrete beam developed intermediate values in the central deflection. As a numerical comparison, the secant flexural stiffness $\left(\mathrm{K}_{1}\right)$ of various beam groups is calculated as the load at $25 \%$ of the ultimate load of each beam-group divided by the corresponding value of central deflection of the same group. The calculated values for various beam-groups are reported in Table (5). As presented in the table, the flexural stiffness of the control beam with normal concrete was found to be $1.811 \mathrm{ton} / \mathrm{mm}$ while the corresponding values of groups $\mathrm{B} \& \mathrm{C}$; with recycled concrete mixes, were $1.639 \& 1.248$ ton $/ \mathrm{mm}$ respectively. This means that the use of recycled concrete mixes in the reinforced concrete beams leads to lower values of the flexural stiffness of the beam and this decrease in the flexural stiffness increases with an increase in the percentage of the crushed concrete in the mix.

Figure (6) shows the variation in the central strain of a bottom steel bar with the applied flexural loading for various beam groups with various recycled concrete mixes. The figure shows that the beam groups with recycled concrete mixes; groups B \& C exhibit higher values of the central steel strain than the control beam with coarse aggregate from gravel. As a comparison between the three beam groups, the value of load corresponding to $25 \%$ of the ultimate load of each group divided by the corresponding value of the central steel strain is defined hereafter as the steel flexural stiffness $\left(\mathrm{K}_{2}\right)$. As shown in Table (5), the measured value of $K_{2}$ of the control beam (group A with $100 \%$ of the coarse aggregate from gravel)) is 0.0422 ton/micro-strain while the corresponding values of beam groups B \& $C$ with 50 $\%$ and $100 \%$ of crushed concrete as a part of the coarse aggregate are 0.0292 and 0.0236 ton/microstrain, respectively. This means that, the addition of crushed concrete as a part of the coarse aggregate leads to an increase in the central strain of the longitudinal steel bars and this consequently increases the stresses developed in such bars till it reaches the yielding state at earlier stages of the applied loads. The variation of strain at an end stirrup with the applied flexural loading is plotted in Fig. (7). Keeping an eye on this figure and looking into the test results presented in Table (5), one can easily notice that, the load at which an end stirrup starts developing strain is getting reduced with an increase in the percentage of crushed concrete as a part of the coarse aggregate in the recycled concrete mix.

\section{Behaviour of Beams with Various Recycled Concrete Mixes under Shear Loading}

Plate (3) shows the cracking patterns of various beam groups with various recycled concrete mixes under the effect of shear loading while the values of both cracking and ultimate loads are presented in Table (6). Considering the experimental test results presented in Table (6), it is noticed that the control beam group with $100 \%$ of the coarse aggregate from gravel; group D, developed a flexural crack at a load of 8.571 ton which is about $65 \%$ of its ultimate load but this crack did not propagate and was rapidly followed by a shear crack observed midway between the point of loading and the nearest support, in the critical shear zone at a load of 9.429 ton which is about $72 \%$ of the ultimate load of the beam. With a further increase in the applied shear load, the shear crack extended to join the edges of the applied load and the nearest support and propagated till the failure of the beam as shear failure at a load of 13.143 ton. Considering the beam groups with recycled concrete; groups $E \& F$, the results show that the same mode of cracking is noticed for all groups but the difference here was the value of the load stage. In case of beamgroup E; made out of recycled concrete with $50 \%$ of the coarse aggregate from crushed concrete, the beam developed its first crack at a load of 7.714 ton; which is about $63 \%$ of its ultimate load, in the mode of flexural crack and also this crack did not propagate, while it was rapidly followed by a shear crack at a load of 8.571 ton which is about $70 \%$ of the ultimate load. The shear crack was propagated with the increase in the applied shear load till the beam failed at a load of 12.286 ton in the mode of shear failure. A further increase in the percentage of crushed concrete to be $100 \%$ of the coarse aggregate in the recycled concrete mix; Group F, has reduced the strength of the beam as the first crack occurred at a load of 7.143 ton which is about $61 \%$ of the ultimate load and was followed by a shear crack at a load of 8.0 ton which is about $68 \%$ of the ultimate load while the beam failed at a load of 11.714 ton in the same mode of shear failure.

Figure (8) shows the load-central deflection relationships of various beam-groups under shear loading. As shown in figure, the relationship is almost linear over most of the load stages. This happened for: the three beam groups with various recycled concrete mixes. The experimental results show that, as the case of flexural loading, the value of central deflection increases with an increase in the percentage of crushed concrete in the coarse aggregate of the recycled concrete mix. Figure (9) shows the variation in the value of the central strain 
in a bottom steel bar with the applied shear load for various beam groups with various percentage ratios of the crushed concrete in the coarse aggregate of the recycled concrete mix. As shown in the figure, the strains in bottom bars increase with an increase in the percentage of crushed concrete in the mix. In Figure (10), the variation in the steel strain at the end of the beam with the applied load is plotted. The figure enhances the understanding that the increase in the percentage of crushed concrete in the mix increases the steel strain.

Numerical comparisons among various beam groups under both flexural and shear loading are held in Tables (7) \& (8) while the same relations are plotted in Figures (11) to (14). Table (7) is concerned with the behaviour of various beam groups under flexural loading. As shown in the table, the first crack occurs in the control beam group with $100 \%$ of the coarse aggregate from gravel, in the mode of flexural crack, at a load of 2.571 ton while this value reduces to about $91 \%$ of that of the control beam when the concrete mix is provided with crushed concrete as $50 \%$ of the coarse aggregate. The first crack occurred in beam-group $C$ with $100 \%$ of the coarse aggregate from crushed concrete at a load of 2.072 ton which is about $81 \%$ of the case of the control beam; group A. When the beams are subjected to shear loading, Table (8) shows that the first crack occurred in the control beam at 8.571 ton and reduced to about $90 \%$ of its value when crushed concrete is added as $50 \%$ of the coarse aggregate. When the beam is provided with recycled concrete with $100 \%$ crushed concrete as the coarse aggregate the value of the first crack load has further reduced to about $83 \%$ only of the corresponding value of the control beam. Again the same observation of the reduction in the performance of the beam with an increase in the percentage of crushed concrete as a part of the coarse aggregate becomes very clear in Tables (7) \& (8) as the value of the load at second crack reduced to about $84 \%$ \& $74 \%$, in case of flexural loading, and about $91 \%$ \& $85 \%$, in case of shear loading, of the corresponding value of the control beam when the percentage of crushed aggregate is $50 \% \& 100 \%$, respectively. Finally the reduction in the ultimate load ranged between about $94 \% \& 85 \%$ in the flexural loading and about $93 \%$ and $89 \%$ in case of shear loading for the two cases of $50 \%$ and $100 \%$ of crushed concrete as a part of the coarse aggregate. The variations in the first crack, second crack and ultimate loads with the percentage of crushed concrete as a part of the coarse aggregate are plotted in figures (11) \& (12). The reduction in the beam stiffness due to crushed concrete is more obvious as it ranged between $56 \%$ and $91 \%$ of the corresponding values of the control beam. Figures (13) \& (14) show the variations in the beam stiffness; $K_{1}$, and steel stiffness; $K_{2}$, with the percentage of crushed concrete as a part of the coarse aggregate.

\section{Codes Provisions for Design of Reinforced \\ Concrete Beams}

Flexural Loading

The analysis and design of doubly reinforced concrete sections subjected to flexure is carried out using the strength equations as follows:

Egyptian Code of Practice ECCS 203-2003.

The design ultinate moment is calculated as follows:

$M_{u}=R_{\max }\left(\frac{f_{\mathrm{cu}}}{\gamma_{\mathrm{c}}}\right) b d^{2}+\left(\frac{f_{\mathrm{y}}}{\gamma_{\mathrm{s}}}\right) A_{s}^{-}\left(d-d^{-}\right)$

The nominal moment of the section is calculated as

$\mathrm{M}_{\mathrm{n}}=0.67 f_{c u} \mathrm{a}^{*} \mathrm{~b}\left(\mathrm{~d}-\frac{\mathrm{a}^{*}}{2}\right)+\mathrm{A}_{\mathrm{s}}^{-} f_{\mathrm{y}}\left(\mathrm{d}-\mathrm{d}^{-}\right)$

while,

$$
\mathrm{a}^{*}=\frac{\left(\mathrm{A}_{\mathrm{s}}-\mathrm{A}_{\mathrm{s}}^{-}\right) f_{\mathrm{y}}}{0.67 f_{c u} \mathrm{~b}}
$$

\section{ACI 318-95}

$\mathrm{M}_{\mathrm{u}}=0.85 f_{\mathrm{c}} \mathrm{a}^{*} \mathrm{~b}\left(\mathrm{~d}-\frac{\mathrm{a}^{*}}{2}\right)+\mathrm{A}_{\mathrm{s}}^{*} f_{\mathrm{y}}\left(\mathrm{d}-\mathrm{d}^{*}\right)$

while,

$$
\mathrm{a}^{*}=\frac{\left(\mathrm{A}_{\mathrm{s}}-\mathrm{A}_{\mathrm{s}}^{-}\right) f_{\mathrm{y}}}{0.85 f_{\mathrm{c}} \mathrm{b}}
$$

In the above equations, in both the ECCS \& the $\mathrm{ACI}$, the stress in the top reinforcement has to be checked for yielding. Otherwise, the yield stress; $f_{y}$, has to be replaced by the actual stress in the compression steel; $f_{\mathrm{s} .}$ As per the ECCS-203, the stresses in top reinforcement may not be checked for yielding in case of $d \%$ does not exceed 0.15 for the case of high grade steel (steel 36/52).

\section{Shear Loading:}

The standard method for shear design of reinforced concrete element uses the concept that the total design shear strength, $V_{d}$, is taken as the sum of the shear carried by concrete, $V_{\mathfrak{c}}$, and the shear carried by the stirrups, $\dot{V}_{\mathrm{s} .}$ Since all shear specimens, in the present study, are considered without stirrups, the design shear strength of the beam; $V_{d}$, is derived from the shear portion carried by concrete only; i.e. $V_{d}=V_{c}$.

Egyptian Code of Practice ECCS 203-2003.

According to the Egyptian Code of practice, ECCS 203-2003, the design shear capacity of concrete elements, $V_{c}$, is estimated using the following empirical equation for beams without stirrups:

$$
\mathrm{V}_{\mathrm{c}}=0.24 \sqrt{f_{c u} / \gamma_{\mathrm{c}}} \mathrm{N} / \mathrm{mm}^{2}
$$

The nominal shear may be estimated as: 


$$
\mathrm{V}_{\mathrm{cn}}=0.24 \sqrt{f_{c u}} \quad \mathrm{~N} / \mathrm{mm}^{2}
$$

ACI 318-95

$$
\mathrm{V}_{\mathrm{c}}=0.16 \sqrt{f_{\mathrm{c}}} \quad \mathrm{N} / \mathrm{mm}^{2}
$$

Zsutty Equation

$$
\mathrm{V}_{\mathrm{c}}=2\left(f_{\mathrm{c}} \mu \frac{\mathrm{d}}{\mathrm{a}}\right)^{1 / 3} \mathrm{~N} / \mathrm{mm}^{2}
$$

where:

$f_{c \prime \prime}=$ Cube comp. strength at 28 days.

$f_{c}=$ Cylinder comp. strength at 28 days

$f_{y}=$ Yield stress of the used steel bars.

$\gamma_{c}=$ Strength reduction factor for concrete

$=1.5$.

$\gamma_{\mathrm{s}}=$ Strength reduction factor for reinforcement $=1.15$.

$A_{s}=$ Area of the bottom reinforcement.

$A_{s}^{-}=$Area of the top reinforcement.

$\mu=$ Main reinforcement ratio

$\mathrm{d}=$ Effective depth of the beam section.

$\mathrm{d}^{-}=$Distance from extreme compression surface of section to the centroid of compression steel.

$\mathrm{b} \quad=$ Width of the rectangular section.

$R_{\max }=0.194$ for high grade steel (steel 36/52).

a = Shear span

Comparisons between the test results and the values predicted from different codes and design equations are presented in Tables (9) \& (10) while the same relations are plotted in Figures (15) \& (16). The results presented in both tables show that for flexural loading, the values of nominal moments calculated using both the ACl-318 and the ECCS-203 are very close to each other, while both of them are relatively lower than the experimental values. The values calculated using design equations given by the ECCS-203 represent conservative estimations to the moment capacity of the section. For shear loading, the values calculated using Zsutty equation gives, relatively, closer results to those obtained experimentally, while the ACI-318 gives a very conservative estimation.

\section{CONCLUSIONS}

Based on the present experimental investigation, the following conclusions can be drawn:

1. The use of recycled concrete in reinforced concrete beams does not affect the failure modes of beams while it greatly affects the values of cracking loads. When the beams are subjected to flexural loading, all beams had their first crack in the mode of flexural cracking. The control beam with normal concrete developed its first crack at load of 2.571 ton which is about $26.5 \%$ of its ultimate load while the second crack occurred, as shear crack, at a load of 7.143 ton which is about $74 \%$ of the ultimate load. The shear crack did not propagate and the beam failed by the propagation of flexural cracks. When recycled concrete is used with $50 \%$ of the coarse aggregate is from crushed concrete, the first and second crack occurred at loads of 2.351 ton and 6.269 ton which are about $25.7 \%$ and $68.6 \%$, respectively, of the ultimate load of the same beam group. The beams made out of recycled concrete with $100 \%$ crushed concrete as coarse aggregate developed their first and second cracks at 2.072 and 5.524 ton. These loads are equivalent to about $25 \%$ and $66.7 \%$ of the ultimate load of the beam. The beams with recycled concrete with both ratios of crushed concrete as coarse aggregate had also their second cracks in the mode of shear cracks while it failed by the propagation of flexural cracks. In case of shear loading, the control beam developed its first crack in the mode of flexural loading at a load of 8.571 ton while this crack did not propagate and was followed by a shear crack at a load of 9.429 ton which is about $72 \%$ of the ultimate load. The beam failed by the propagation of shear cracks. In cases of beams with recycled concrete with $50 \%$ and $100 \%$ of the coarse aggregate from crushed concrete, the beams developed their first cracks at loads of 7.714 \& 7.143 ton which are about $63 \% \& 61 \%$ of the ultimate loads of beams. These cracks had the mode of flexural cracks while it did not, also, propagate and followed by shear cracks at loads of 8.571 and 8.0 ton which are about $70 \%$ and $69 \%$ respectively of the ultimate loads of beams. The beams failed by the propagation of shear cracks.

2. The use of recycled concrete in reinforced concrete beams reduces the load carrying capacity of beams in both cases of flexural and shear loading. The reduction in the performance of the beam increases with an inorease in the percentage ratio of crushed concrete as a part of the coarse aggregate. When the beams are subjected to flexural loading, the control beam group failed at a load of 9.714 ton while, this value has reduced to 9.143 ton which is about $94 \%$ of the corresponding value of the control beam when the concrete mix was provided with crushed concrete as $50 \%$ of the coarse aggregate. A further increase in the percentage of crushed concrete in the mix to be $100 \%$ of the coarse aggregate has reduced the ultimate load of the beam to about 85 $\%$ only of the corresponding value of the control beam. In case of shear loading the control beam failed at a load of 13.143 ton while the beam with recycled concrete with $50 \%$ of the coarse aggregate from crushed concrete exhibited a failure load of 12.286 ton which is about $93 \%$ 
only of that of the control beam. When crushed concrete is used a $100 \%$ of the coarse aggregate the ultimate load of the beam was 11.714 ton which is about $89 \%$ only of the corresponding value of the control beam.

3. The use of recycled concrete in reinforced concrete beams leads to higher values of the central deflection of the beams. This means a reduction in the flexural stiffness of the beam. When the secant flexural stiffness is calculated as the load at $25 \%$ of the ultimate load divided by the corresponding value of the central deflection, the control beam exhibited stiffness of 1.811 and $4.032 \mathrm{ton} / \mathrm{mm}$ in both cases of flexural and shear loading, respectively. The beam stiffness is reduced to about $91 \%$ and $78 \%$ of the corresponding values of the control beam in both cases of flexural and shear loading, respectively, when $50 \%$ of the coarse aggregate is from crushed concrete. A further increase in the crushed concrete to be $100 \%$ of the coarse aggregate has reduced the beam stiffness to about $69 \%$ and $64 \%$ of the corresponding values of the control beam in both flexural and shear loading.

4. The use of recycled concrete in reinforced concrete beams increases the strains in the main reinforcement of the beam. The increase in such strains increases with an increase in the percentage ratio of crushed concrete in the coarse aggregate.

5. The equations of the Egyptian Code for Design and Construction of Reinforced Concrete Structures; ECCS 203-2003 may be used for the flexural design of reinforced concrete beams made out of recycled concrete without great loss of accuracy. The results show that, for flexural loading, the values of nominal moments calculated using both the ACI-318 and the ECCS203 are very close to each other, while both of them are relatively lower than the experimental values. The values calculated using design equations given by the ECCS-203 represent conservative estimations to the moment capacity of the section.

6. The ACI 318-95 Code of practice gives a very conservative estimation for the shear capacity of reinforced concrete beams made out of recycled concrete. On the other hand, Zsutty equation predicts values, which are, relatively, closer to the experimental results.

\section{REFERENCES}

[1] ACI 318 (1995) "Building Code Requirements for Reinforced Concrete, "American Concrete Institute, Detroit, 1995.

[2] Egyptian Standard, ES:1109-1971, "Concrete Aggregates From Natural Sources", Egyptian
Organization for Standardization and Quality Control, Egypt, 1971.

[3] Egyptian Standard, ES: 1658-1993, "Testing Concrete", Egyptian Organization for Standardization and Quality Control, Egypt, 1993.

[4] Egyptian Standard, ES: 2421-1993, "CementPhysical and Mechanical Testing ", Egyptian Organization for Standardization and Quality Control, Egypt, 1993.

[5] Egyptian Code for Design and Construction of Reinforced Concrete Structures, Ministry of Housing and Urbanization, (EGCP-1995), Fourth Edition, Cairo, Egypt, 1998.

[6] Egyptian Code for Design and Construction of Reinforced Concrete Structures, Ministry of Housing and Urbanization, (ECCS 203-2003), Second Revision, Eighth Edition, Cairo, Egypt, 2003.

[7] Environmental Resources Ltd., "Demolition Waste," The Construction Press Ltd., pp. 175, 1980.

[8] Frondistou-Yannas, S. T., "Waste Concrete as Aggregate for New Concrete", ACI Journal, Proceedings Vol. 74, No. 8, pp. 373-376, 1977.

[9] Jin-Keun K., and Yon-Dong P., "Prediction of Shear Strength of Reinforced Concrete Beams without Web Reinforcement" ACI Materials Journal, Vol. 93, No. 3, May-June, 1996, pp. 213-222.

[10] James G. MacGregor, "Reinforced concrete Mechanics and design," Prentice-Hall International, New Jersey, 939 pp. 1997.

[11] Mehta, P. K., "Concrete Structures, Properties and Materials", Prentice-Hall, Inc., Englewood, New Jersey, 1986.

[12] Mulheron, M., and O'Mahony, M., "The Durability of Recycled Aggregates and Recycled Aggregate Concrete", Proceedings of the $2^{\text {nd }}$ International RILEM Symposium, Tokyo, Japan, pp. 633-642, 1988.

[13] Matthana, M. H., and Tahwia, A. M., "Strength Properties of Recycled Concrete", The $2^{\text {nd }}$ Minia International Conference For Advanced Trends in Engineering,7-9 April, 2002, ElMinia University, El-Minia, Egypt, pp. 444455.

[14] Rasheeduzzafar, and Khan, A., "Recycled Concrete -A source of New Aggregate", Cement, Concrete and Aggregate, Vol. 6, No. 1, pp. 17-27, 1984.

[15] Salem, R., M., and Burdette, E. G., "Role of Chemical and Mineral Admixtures on Physical Properties and Frost-Resistance of Recycled Aggregate Concrete", ACI Materials Journal, pp. 558-563, September-October, 1998.

[16] Tavakoli, M., and Soroushian, P., "Strengths of Recycled Aggregate Concrete Made Using 
Field-Demolished Concrete as Aggregate", ACI Materials Journal, pp. 182-191, March-April 1996.

TABLE (1) Physical Properties of Coarse Aggregate

\begin{tabular}{||c|c|c|}
\hline \multicolumn{1}{|c|}{ Property } & G* $^{*}$ & C-C* \\
\hline Bulk Unit Weight $\left(\mathrm{g} \backslash \mathrm{cm}^{3}\right)$ & 1.712 & 1.753 \\
\hline Water Absorption \% & 0.82 & 6.31 \\
\hline
\end{tabular}

[17] Theodore C. Zsutty, "Shear Strength Prediction for Separate Categories of Simple Beam Tests, "ACI Journal, Vol. 68, No. 2, pp. 138-143, February 1971.

TABLE (2) Mix Proportions for both Normal and Recycled Concrete

\begin{tabular}{|c|c|c|c|c|c|c|c|}
\hline \multirow{2}{*}{ Type of Mix } & \multicolumn{5}{|c|}{ Material Weights (Kg) } & \multirow{2}{*}{$\begin{array}{c}\text { Water / } \\
\text { Cement } \\
\text { Ratio }\end{array}$} & \multirow{2}{*}{ Slump } \\
\hline & Cement & Sand & $G^{*}$ & $\mathrm{C}-\mathrm{C}^{*}$ & Water & & \\
\hline (Mix 1) $0 \% \mathrm{C}-\mathrm{C}^{*}+100 \% \mathrm{G}^{*}$ & 28 & 60 & 95 & 0 & 14 & 0.5 & 8 \\
\hline$(\operatorname{Mix} 2) 50 \%$ C-C ${ }^{*}+50 \% \mathrm{G}^{*}$ & 28 & 60 & 47.5 & 47.5 & 14 & 0.5 & 9 \\
\hline$($ Mix 3) $100 \%$ C-Concrete $+0 \%$ G* & 28 & 60 & 0 & 95 & 14 & 0.5 & 10 \\
\hline
\end{tabular}

* $\mathrm{G}=$ Gravel \& $\mathrm{C}-\mathrm{C}=$ Coarse Aggregate from Crushed Concrete.

TABLE (3) Strength Properties of Various Concrete Mixes

\begin{tabular}{|c|c|c|c|c|c|c|c|c|}
\hline \multirow{3}{*}{$\begin{array}{l}\text { \% of Coarse } \\
\text { Aggregate } \\
\text { from Crushed } \\
\text { Concrete }\end{array}$} & \multirow{2}{*}{\multicolumn{2}{|c|}{ Compressive Strength }} & \multicolumn{4}{|c|}{ Tensile Strength } & \multicolumn{2}{|c|}{ Young's Modulus } \\
\hline & & & \multicolumn{2}{|c|}{ Splitting } & \multicolumn{2}{|c|}{ Flexural } & & \\
\hline & $\mathrm{Kg} / \mathrm{cm}^{2}$ & Norm. \% & $\mathrm{Kg} / \mathrm{cm}^{2}$ & Norm. $\%$ & $\mathrm{Kg} / \mathrm{cm}^{2}$ & Norm.\% & $\mathrm{Kg} / \mathrm{cm}^{2}$ & Norm. \% \\
\hline 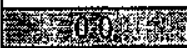 & 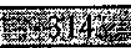 & 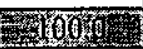 & 3. & 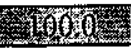 & 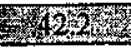 & 10000 & 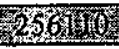 & 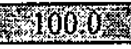 \\
\hline 50.0 & 274 & 87.3 & 23.8 & 86.2 & 38.2 & 90.5 & 188978 & 73.8 \\
\hline 100.0 & 213 & 67.8 & 19.8 & 71.7 & 33.6 & 79.6 & 142038 & 55.5 \\
\hline
\end{tabular}

TABLE (4) Details of the Experimental Test Specimens

\begin{tabular}{|c|c|c|c|c|c|c|c|c|c|}
\hline $\begin{array}{c}\text { Group } \\
\text { No. }\end{array}$ & $\begin{array}{l}\text { Type of } \\
\text { Loading }\end{array}$ & $\begin{array}{c}\text { No. of } \\
\text { Specimens }\end{array}$ & $\begin{array}{l}\text { Mix } \\
\text { No. }\end{array}$ & $\begin{array}{c}\text { Dimensions } \\
\text { b x t }\end{array}$ & $\begin{array}{l}\text { Bottom } \\
\text { Rft. }\end{array}$ & $\begin{array}{l}\text { Top } \\
\text { Rft. }\end{array}$ & Stirrups & $\bar{a}$ & $a / d$ \\
\hline $\mathbf{A}$ & \multirow{3}{*}{$\begin{array}{l}\text { Flexural } \\
\text { Loading }\end{array}$} & 3 & 1 & \multirow{3}{*}{$12 \times 20$} & \multirow{3}{*}{$2 \phi 16$} & \multirow{3}{*}{$2 \phi 10$} & \multirow{3}{*}{$\begin{array}{c}\phi 6 @ 10 \\
\mathrm{~cm}\end{array}$} & \multirow{3}{*}{55} & \multirow{3}{*}{3.235} \\
\hline $\bar{B}$ & & 3 & 2 & & & & & & \\
\hline $\mathrm{C}$ & & 3 & 3 & & & & & & \\
\hline D & \multirow{3}{*}{$\begin{array}{l}\text { Shear } \\
\text { Loading }\end{array}$} & 3 & 1 & \multirow{3}{*}{$12 \times 20$} & \multirow{3}{*}{$2 \phi 16$} & \multirow{3}{*}{$2 \phi 10$} & \multirow{3}{*}{------ } & \multirow{3}{*}{27.5} & \multirow{3}{*}{1.618} \\
\hline $\mathbf{E}$ & & 3 & 2 & & & & & & \\
\hline F & & 3 & 3 & & & & & & \\
\hline
\end{tabular}

TABLE (5) Experimental Results of Beams with Various Mixes under Flexural Loading

\begin{tabular}{|c|c|c|c|c|}
\hline & & $\begin{array}{c}\text { Group A } \\
(100 \% \mathrm{G})\end{array}$ & $\begin{array}{c}\text { Group B } \\
(50 \% \mathrm{G}+50 \% \mathrm{C} . \mathrm{C})\end{array}$ & $\begin{array}{c}\text { Group C } \\
(100 \% \text { C. C })\end{array}$ \\
\hline \multirow{2}{*}{ First Crack } & Load (ton) & 2.571 & 2.351 & 2.072 \\
\hline & Mode of Cracking & Flexure & Flexure & Flexure \\
\hline \multirow{2}{*}{ Second Crack } & Load (ton) & 7.143 & 6.269 & 5.524 \\
\hline & Mode of Cracking & Shear & Shear & Shear \\
\hline \multicolumn{2}{|c|}{ Ultimate Load (ton) } & 9.714 & 9.143 & 8.286 \\
\hline \multicolumn{2}{|c|}{ Failure Mode } & Flexure & Flexure & Flexure \\
\hline \multicolumn{2}{|c|}{ Load at First Crack / Ultimate Load } & $26.47 \%$ & $25.71 \%$ & $25.01 \%$ \\
\hline \multicolumn{2}{|c|}{ Load at Second Crack / Ultimate Load } & $73.53 \%$ & $68.57 \%$ & $66.67 \%$ \\
\hline \multirow{3}{*}{$\begin{array}{l}\text { Central } \\
\text { Deflection }(\mathrm{mm})\end{array}$} & At First Cracking Load & 1.393 & 1,438 & 1.660 \\
\hline & At $25 \%$ of Ultimate Load & 1.341 & 1.395 & 1.660 \\
\hline & At Ultimate Load & 7.479 & 9.440 & 9.900 \\
\hline \multirow{2}{*}{\begin{tabular}{|l|} 
Central Steel \\
Strain $\left(\times 10^{-6}\right)$ \\
\end{tabular}} & At First Cracking Load & 61.987 & 80.410 & 87.852 \\
\hline & At $25 \%$ of Ultimate Load & 57.498 & 78.233 & 87.820 \\
\hline \multicolumn{2}{|c|}{ Load at which the end stirrup starts straining (ton) } & 6.143 & 4.680 & 3.386 \\
\hline \multicolumn{2}{|c|}{ Beam Flexural Stiffness; $\mathrm{K}_{\mathrm{l}}$ (ton/mm)* } & 1.811 & 1.639 & 1.248 \\
\hline \multicolumn{2}{|c|}{ Steel Flexural Stiffness $\mathrm{K}_{2}$ (ton/micro strain)* } & 0.0422 & 0.0292 & 0.0236 \\
\hline
\end{tabular}

* Secant Stiffness at $25 \%$ of Ultimate Load 
TABLE (6) Experimental Results of Beams with Various Mixes under Shear Loading

\begin{tabular}{|c|c|c|c|c|}
\hline & & $\begin{array}{r}\text { Group D } \\
(100 \% \mathrm{G})\end{array}$ & $\begin{array}{c}\text { Group E } \\
(50 \% \mathrm{G}+50 \% \mathrm{C} . \mathrm{C}) \\
\end{array}$ & $\begin{array}{c}\text { Group F } \\
(100 \% \text { C. C) }\end{array}$ \\
\hline \multirow{2}{*}{ First Crack } & Load (ton) & 8.571 & 7.714 & 7.143 \\
\hline & Mode of Cracking & Flexure & Flexure & Flexure \\
\hline \multirow{2}{*}{ Second Crack } & Load (ton) & 9.429 & 8.571 & 8.00 \\
\hline & Mode of Cracking & Shear & Shear & Shear \\
\hline \multicolumn{2}{|c|}{ Ultimate Load (ton) } & 13.143 & 12.286 & 11.714 \\
\hline \multicolumn{2}{|l|}{ Failure Mode } & Shear & Shear & Shear \\
\hline \multicolumn{2}{|c|}{ Load at First Crack / Ultimate Load \% } & 65.213 & 62.787 & 60.978 \\
\hline \multicolumn{2}{|c|}{ Load at Second Crack / Ultimate Load \% } & 71.742 & 69.762 & 68.294 \\
\hline \multirow{2}{*}{$\begin{array}{l}\text { Central Deflection } \\
(\mathrm{mm})\end{array}$} & At $25 \%$ of Ultimate Load & 0.815 & 0.983 & 1.137 \\
\hline & At Ultimate Load & 7.43 & 7.07 & 5.93 \\
\hline \multirow{3}{*}{$\begin{array}{l}\text { Central Steel Strain } \\
\left(x \quad 10^{-6}\right)\end{array}$} & At $25 \%$ of Ultimate Load & 21 & 23.33 & 30.50 \\
\hline & At First Cracking Load & 65.3 & 79.1 & 79.71 \\
\hline & At Second Cracking Load & 82.48 & 88.159 & 89.236 \\
\hline \multirow{3}{*}{$\begin{array}{l}\text { End Steel Strain } \\
\left(x 10^{-6}\right)\end{array}$} & At $25 \%$ of Ultimate Load & 15.5 & 21.66 & 33.83 \\
\hline & At First Cracking Load & 96.43 & 97.47 & 103.29 \\
\hline & At Second Cracking Load & 106.786 & 113.148 & 121.213 \\
\hline \multicolumn{2}{|c|}{ Beam Flexural Stiffness; $K_{1}(\text { ton } / \mathrm{mm})^{*}$} & 4.032 & 3.125 & 2.576 \\
\hline \multicolumn{2}{|c|}{ Steel Flexural Stiffness $K_{2}$ (ton/micro strain) ${ }^{*}$} & 0.1565 & 0.1317 & 0.0960 \\
\hline
\end{tabular}

* Secant Stiffness at $25 \%$ of Ultimate Load

TABLE (7) Comparison between Various Beam-Groups under Flexural Loading

\begin{tabular}{|l|c|c|c|c|c|c|}
\hline \hline \multirow{2}{*}{} & Group A & \multicolumn{2}{c|}{ Group B } & \multicolumn{2}{|c|}{ Group C } \\
\cline { 2 - 7 } & Value & $\begin{array}{c}\text { \%of } \\
\text { Group A }\end{array}$ & $\begin{array}{c}\text { Value } \\
\text { \% of } \\
\text { Group A }\end{array}$ & Value & $\begin{array}{c}\text { \% of } \\
\text { Group A }\end{array}$ \\
\hline Load at First Crack (ton) & 2.571 & 100 & 2.351 & 91.443 & 2.072 & 80.591 \\
\hline Load at Second Crack (ton & 7.143 & 100 & 6.269 & 84.397 & 5.524 & 74.367 \\
\hline Ultimate load (ton) & 9.714 & 100 & 9.143 & 94.122 & 8.286 & 85.300 \\
\hline Beam Stiffness K (ton/mm) & 1.811 & 100 & 1.639 & 90.502 & 1.248 & 68.912 \\
\hline Steel Stiffness K K $_{2}$ (ton/micro-strain) & 0.042 & 100 & 0.029 & 69.194 & 0.023 & 55.924 \\
\hline Load at which end stirrup starts straining (ton) & 6.143 & 100 & 4.680 & 76.184 & 3.386 & 55.120 \\
\hline
\end{tabular}

TABLE (8) Comparison between Various Beam-Groups under Shear Loading

\begin{tabular}{|l|c|c|c|c|c|c|}
\hline \multirow{2}{*}{} & \multicolumn{2}{|c|}{ Group D } & \multicolumn{2}{c|}{ Group E } & \multicolumn{2}{c|}{ Group F } \\
\cline { 2 - 7 } & Value & $\begin{array}{c}\% \text { of } \\
\text { Group D }\end{array}$ & Value & $\begin{array}{c}\% \text { of } \\
\text { Group D }\end{array}$ & Value & $\begin{array}{c}\text { \% of } \\
\text { Group D }\end{array}$ \\
\hline Load at First Crack (ton) & 8.571 & 100 & 7.714 & 90.001 & 7.143 & 83.339 \\
\hline Load at Second Crack (ton & 9.429 & 100 & 8.571 & 90.900 & 8.000 & 84.845 \\
\hline Ultimate load (ton) & 13.143 & 100 & 12.286 & 93.479 & 11.714 & 89.127 \\
\hline Beam Stiffness K (ton/mm) & 4.032 & 100 & 3.125 & 77.505 & 2.576 & 63.889 \\
\hline Steel Stiffness K $\mathrm{K}_{2}$ (ton/micro-strain) & 0.1565 & 100 & 0.1317 & 84.153 & 0.0960 & 61.342 \\
\hline
\end{tabular}

TABLE (9) Comparison between Various Beam-Groups Subjected to Flexural Loading

\begin{tabular}{|c|c|c|c|c|c|c|c|}
\hline \multirow{2}{*}{\multicolumn{2}{|c|}{$\begin{array}{l}\text { Value of Ultimate Moment } \\
\text { (m.ton) }\end{array}$}} & \multicolumn{2}{|c|}{ Group A } & \multicolumn{2}{|c|}{ Group B } & \multicolumn{2}{|c|}{ Group C } \\
\hline & & Value & $\begin{array}{c}\text { \% of } \\
\text { Group A }\end{array}$ & Value & $\begin{array}{c}\% \text { of } \\
\text { Group A }\end{array}$ & Value & $\begin{array}{c}\text { \% of } \\
\text { Group A }\end{array}$ \\
\hline \multicolumn{2}{|c|}{ Experimental Value } & 2.671 & 100 & 2.514 & 94.122 & 2.279 & 85.323 \\
\hline \multirow{2}{*}{$\begin{array}{l}\text { ECCS 203- } \\
2003\end{array}$} & Design Value & 2.121 & 100 & 1.942 & 91.561 & 1.668 & 78.642 \\
\hline & Nominal Value & $2.154^{4}$ & 1001 & $2.134^{4}$ & 99.071 & 2.092 & 97.122 \\
\hline \multicolumn{2}{|l|}{$\widehat{A C 1318}$} & $2.162^{*}$ & 100 & $2.142^{*}$ & 99.075 & $2.104^{\circ}$ & 97.317 \\
\hline
\end{tabular}

* The Compression steel has stress less than the yield stress of the used steel.

TABLE (10) Comparison between Various Beam-Groups Subjected to Shear Loading

\begin{tabular}{|c|c|c|c|c|c|c|c|}
\hline \multirow{2}{*}{\multicolumn{2}{|c|}{$\begin{array}{l}\text { Value of Ultimate Shear Load } \\
\text { (ton) }\end{array}$}} & \multicolumn{2}{|c|}{ Group D } & \multicolumn{2}{|c|}{ Group E } & \multicolumn{2}{|c|}{ Group F } \\
\hline & & Value & $\begin{array}{l}\text { \% of } \\
\text { Group D }\end{array}$ & Value & $\begin{array}{c}\% \text { of } \\
\text { Group D }\end{array}$ & Value & $\begin{array}{c}\% \text { of } \\
\text { Group D }\end{array}$ \\
\hline \multicolumn{2}{|c|}{ Experimental Value } & 6.572 & $100 \%$ & 6.143 & 93.47 & 5.857 & 89.12 \\
\hline \multirow{2}{*}{$\begin{array}{l}\text { ECCS 203 } \\
2003\end{array}$} & Design Value & 2.262 & $100 \mathrm{~s}$ & 2.113 & 93.41 & 1.863 & 82.36 \\
\hline & Nominal Value & 2.770 & 100 & 2.588 & 93.43 & 2.282 & 82.38 \\
\hline \multicolumn{2}{|l|}{$\mathrm{ACI} 318$} & 1.703 & 100 & 1.591 & 93.42 & 1.402 & 82.33 \\
\hline \multicolumn{2}{|c|}{ Zustty Equation } & 2.843 & 100 & 2.716 & 95.53 & 2.498 & 87.86 \\
\hline
\end{tabular}




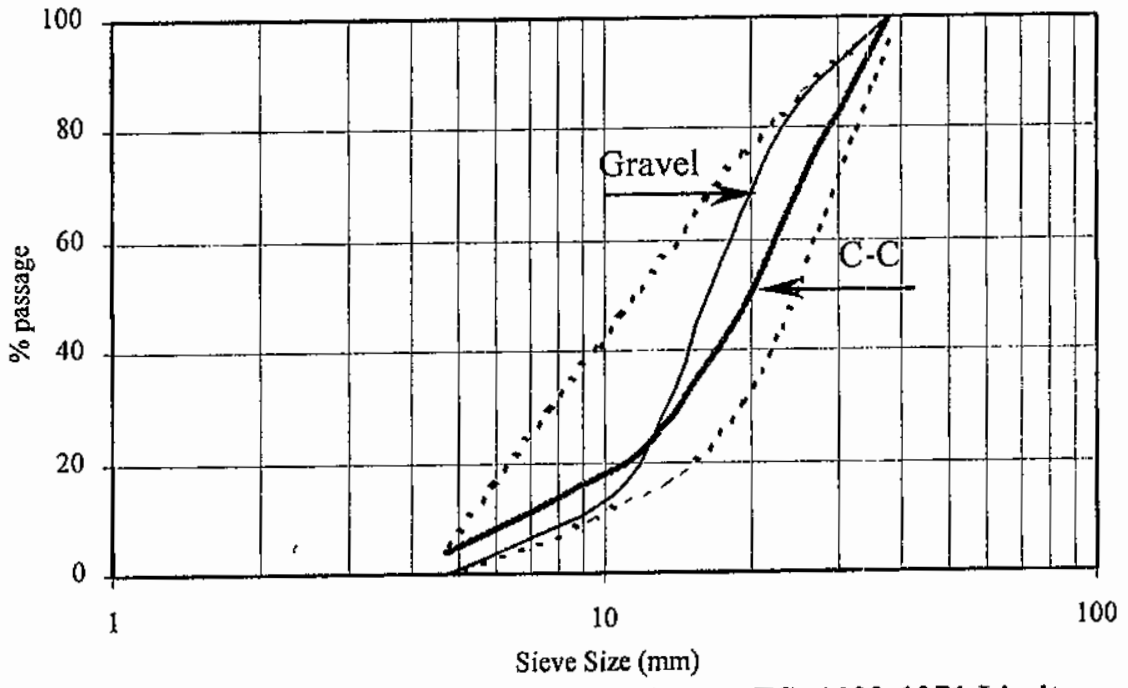

Fig. (1) Grading of Coarse Aggregates with the ES: 1109-1971 Limits

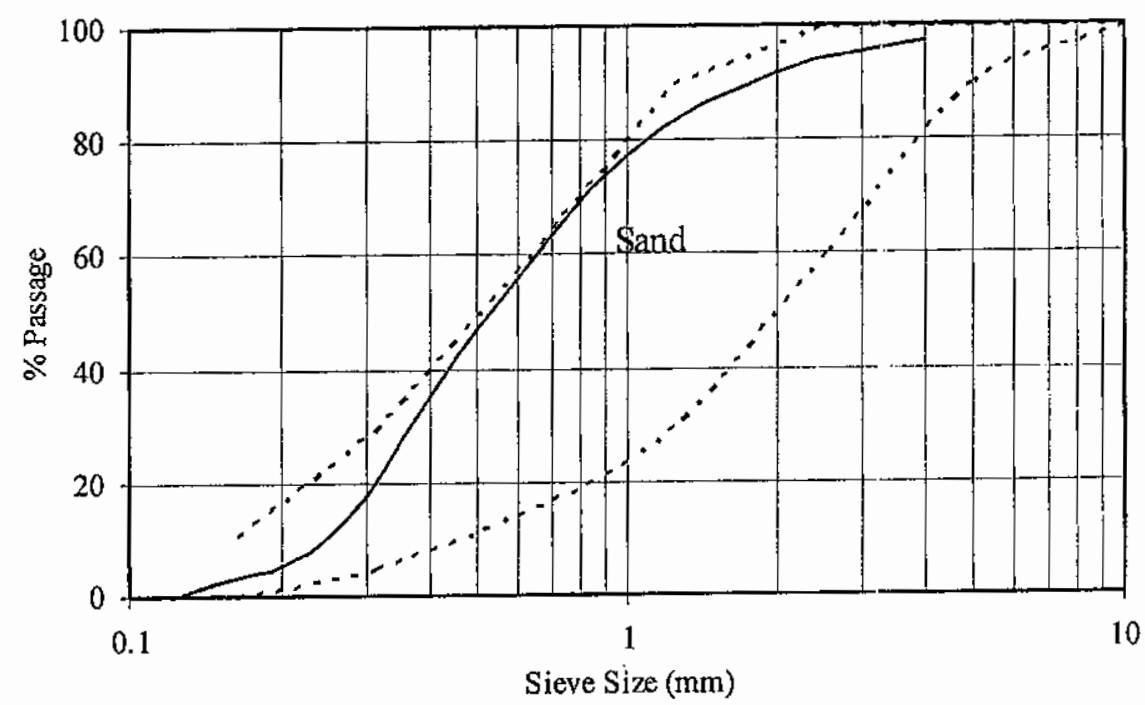

Fig. (2) Grading of Fine Aggregate with the ES: 1109-1971 Limits (Coarse Sand)

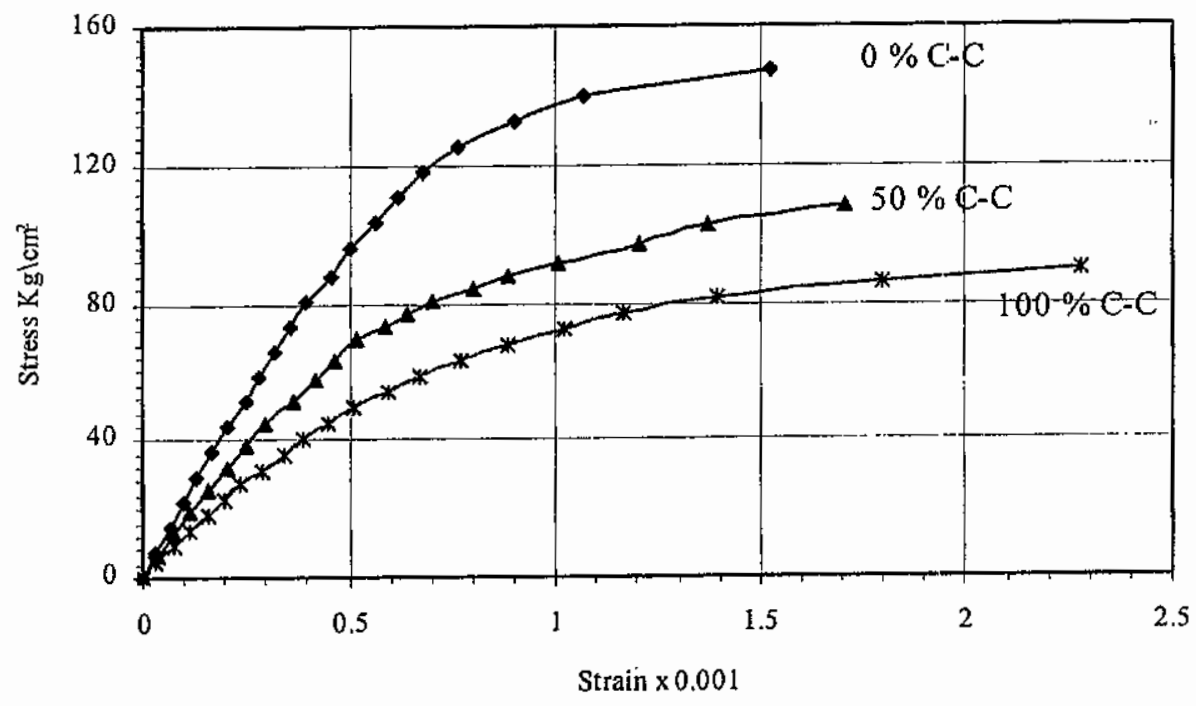

Fig. (3) Stress-Strain Behaviour of Recycled Concrete with Various Percentage Ratios of Crushed Concrete as a part of the Coarse Aggregate 
Mohamed H. Matthana, "Beahaviour of Reinforced Concrete Beams Made out of Recycled Concrete"
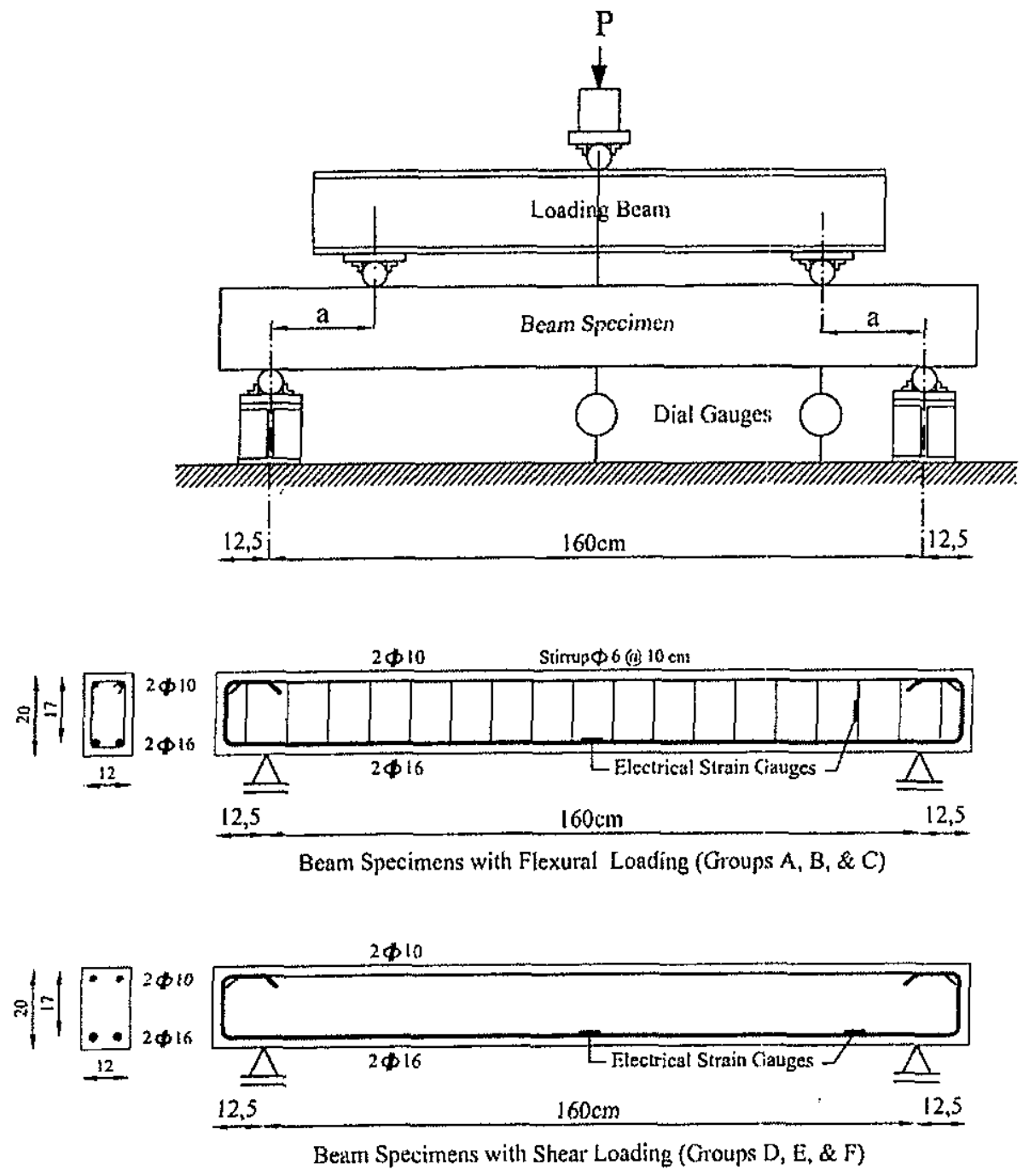

Fig. (4) Configurations of the Experimental Test Specimens and Test Set-Up

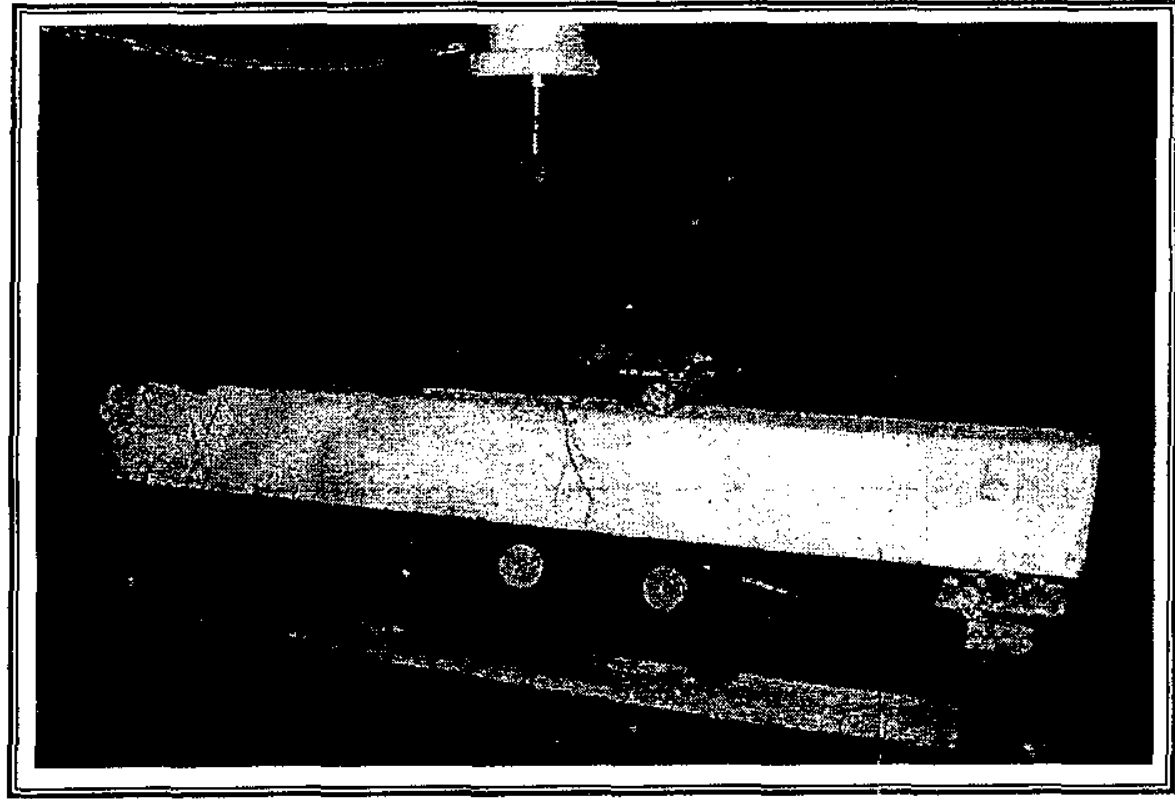

Plate (1) Configurations of the Experimental Test Set-Up

Engineering Research Journal, Minoufiya University, Vol.28, No.4, October 2005 


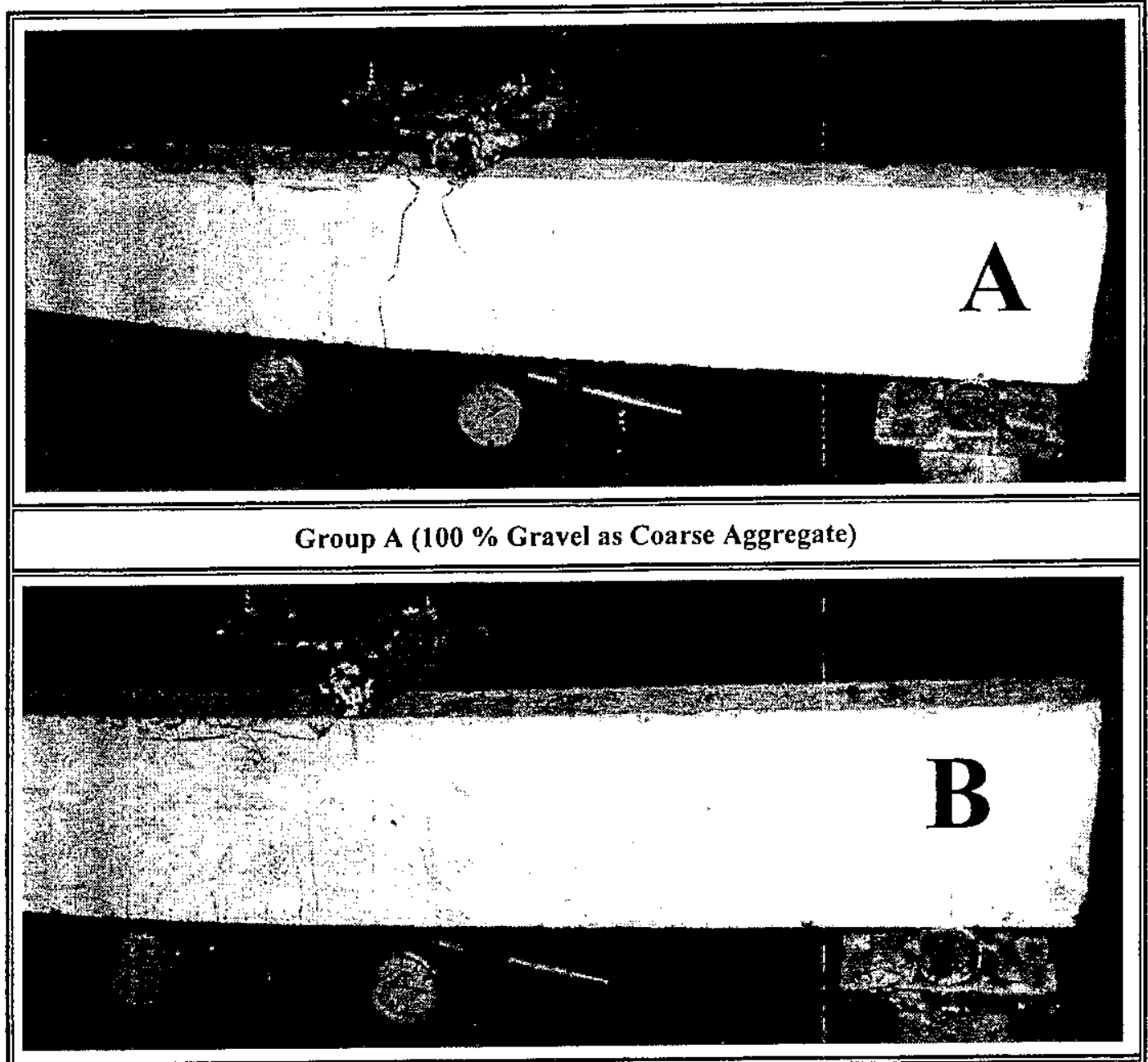

Group B (50\% Gravel + 50\% Crushed Concrete as Coarse Aggregate)

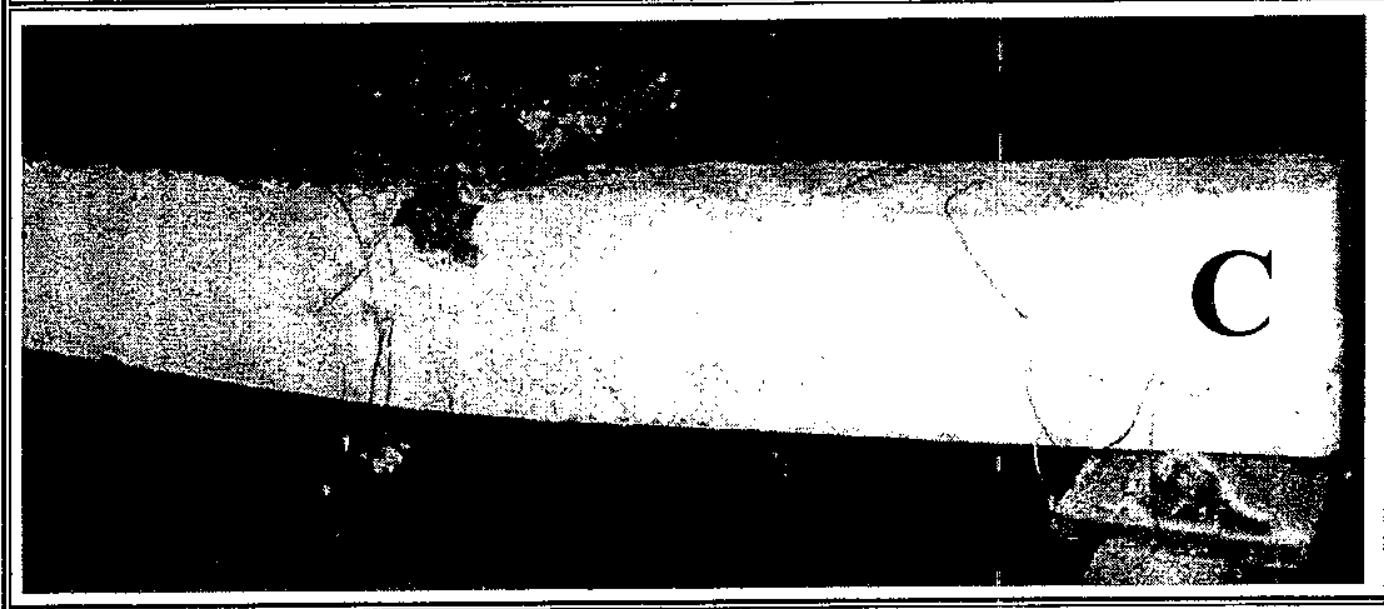

Group C (100\% Crushed Concrete as Coarse Aggregate)

Plate (2) Cracking Patterns of Various Beam-Groups with Various Recycled Concrete Mixes under Flexural Loading 
Mohamed H. Matthana, "Beahaviour of Reinforced Concrete Beams Made out of Recycled Concrete"

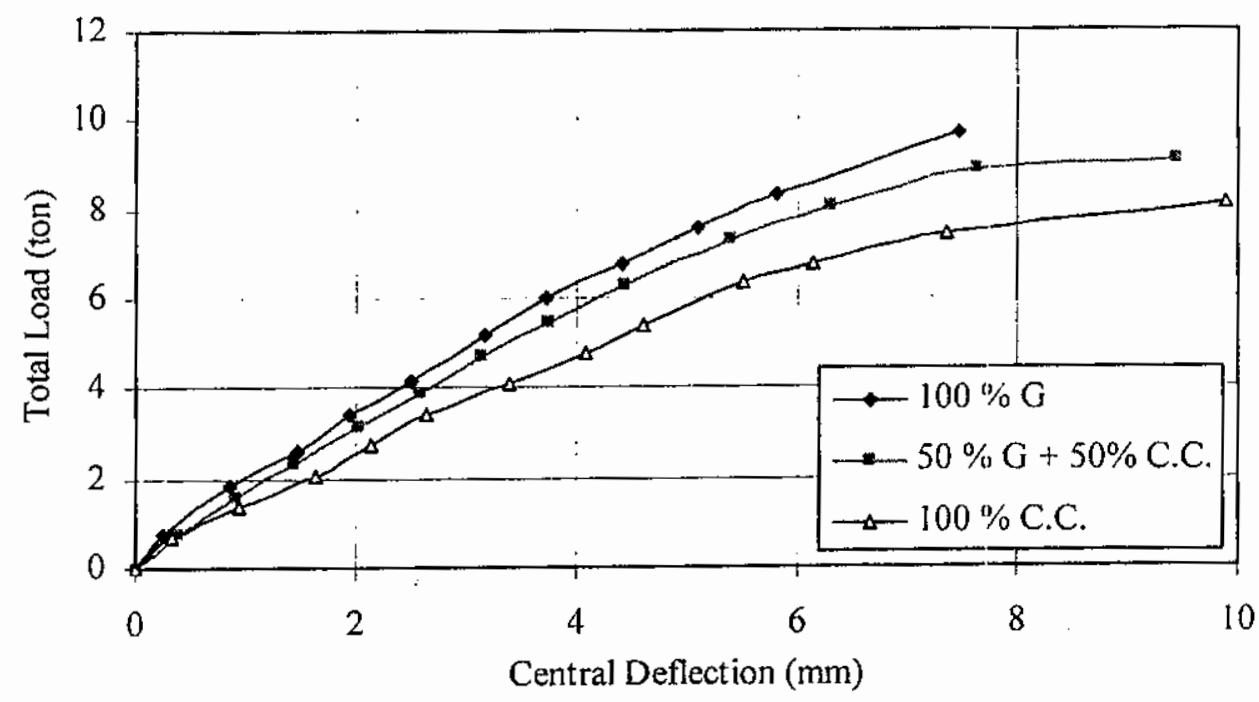

Fig. (5) Load-Deflection Relationship at the Center Lines of Various Beams with Various Recycled Concrete Mixes under Flexural loading

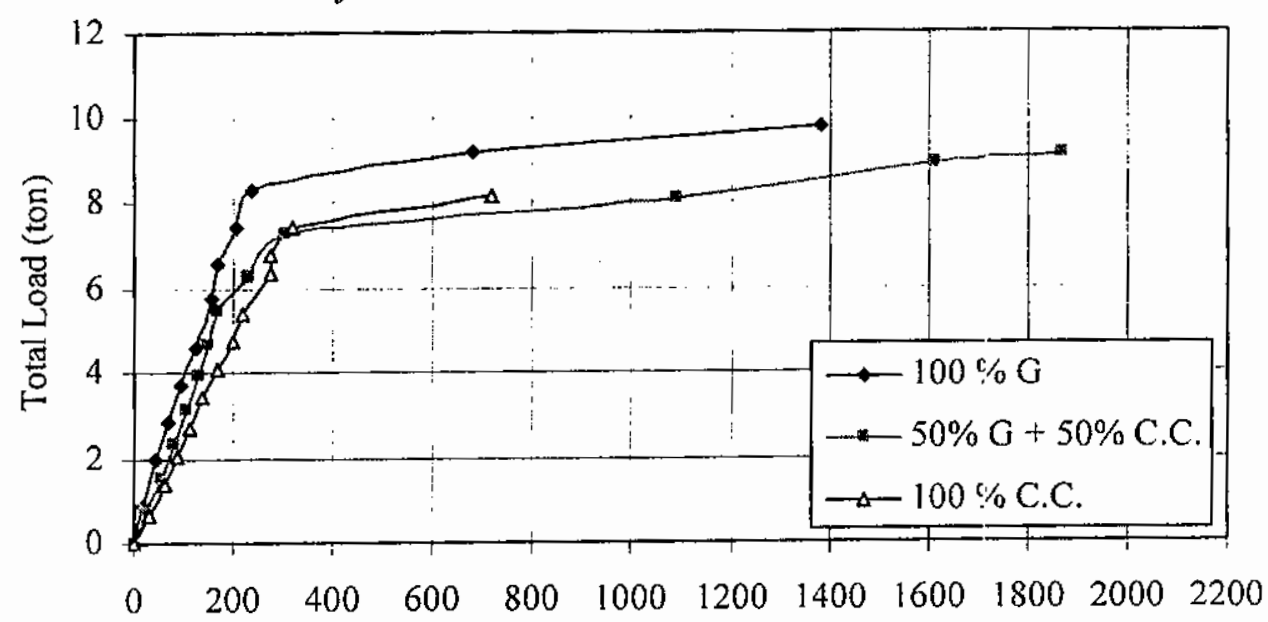

Strain in Bottom Steel Bars at CL x $10^{-6}$

Fig. (6) Variation in the Strain of Bottom Steel Bars at the Centre Lines of Various Beams with Various Recycled Concrete Mixes under Flexural loading

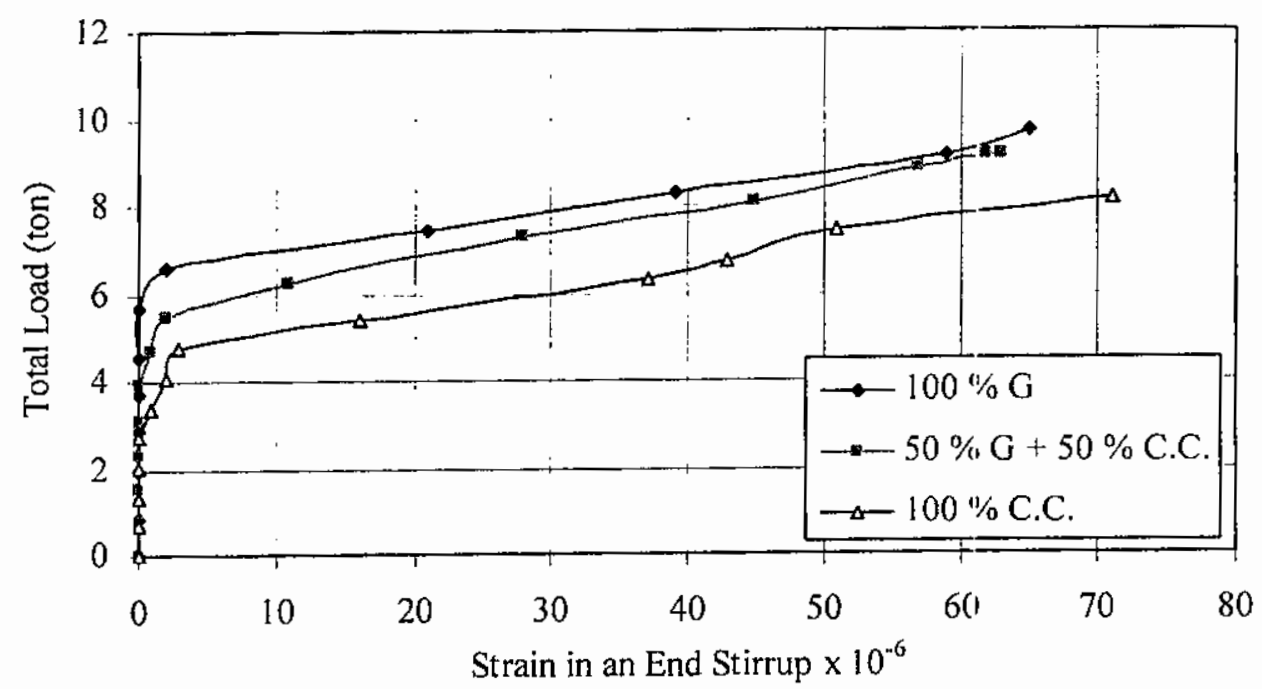

Fig. (7) Variation in the Strain of Stirrups at the End of Various Beams with Various Recycled Concrete Mixes under Flexural loading 


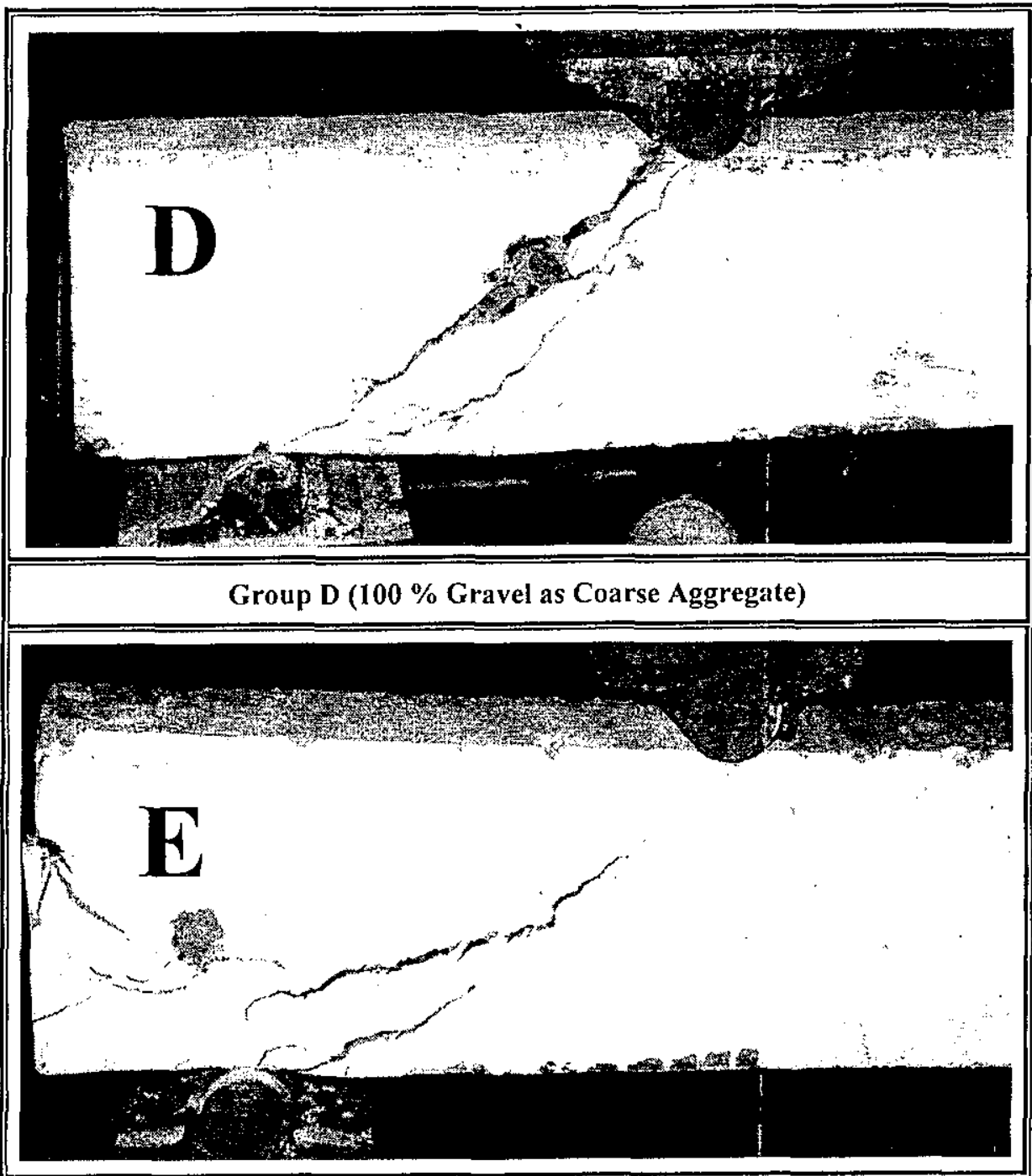

Group E (50\% Gravel + 50\% Crushed Concrete as Coarse Aggregate)

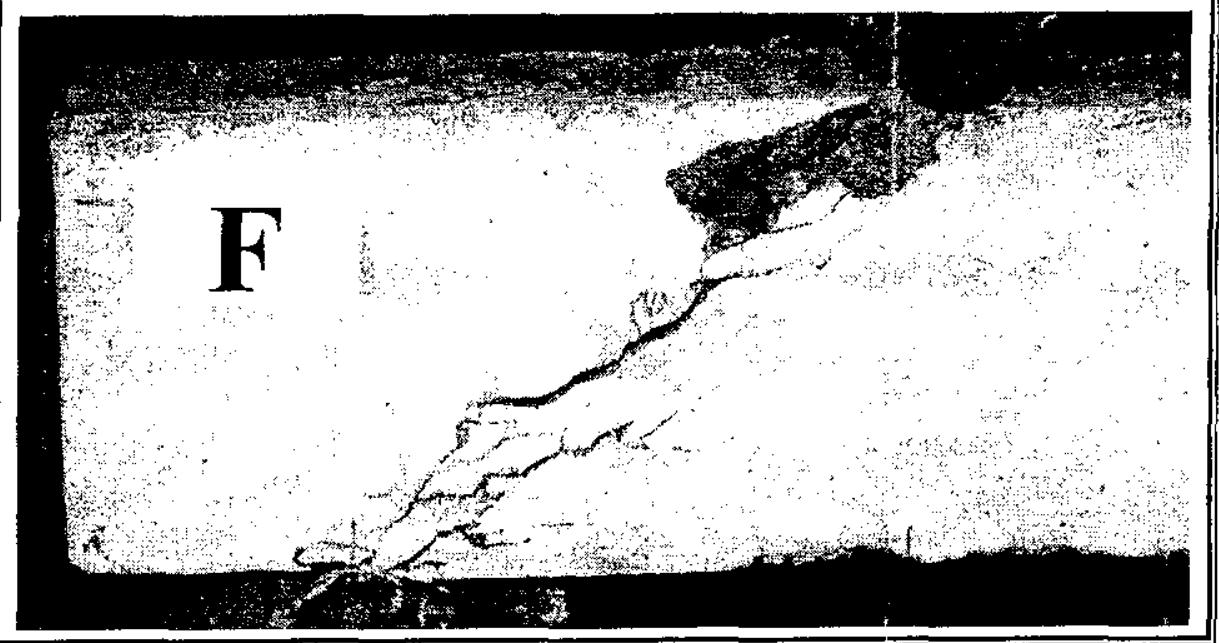

Group F (100\% Crushed Concrete as Coarse Aggregate)

Plate (3) Cracking Patterns of Various Beam-Groups with Various Recycled Concrete Mixes under Shear Loading 
Mohamed H. Matthana, "Beahaviour of Reinforced Concrete Beams Made out of Recycled Concrete"

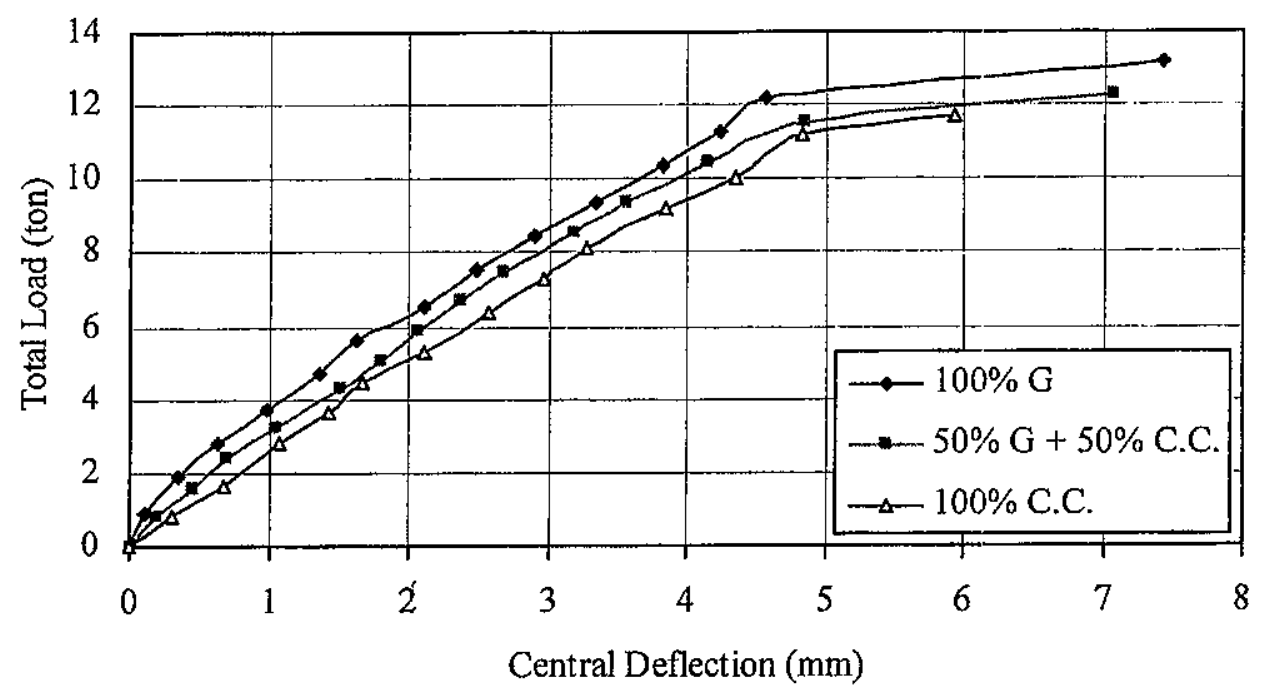

Fig. (8) Load-Deflection Relationship at the Center Lines of Various Beams with Various Recycled Concrete Mixes under Shear loading

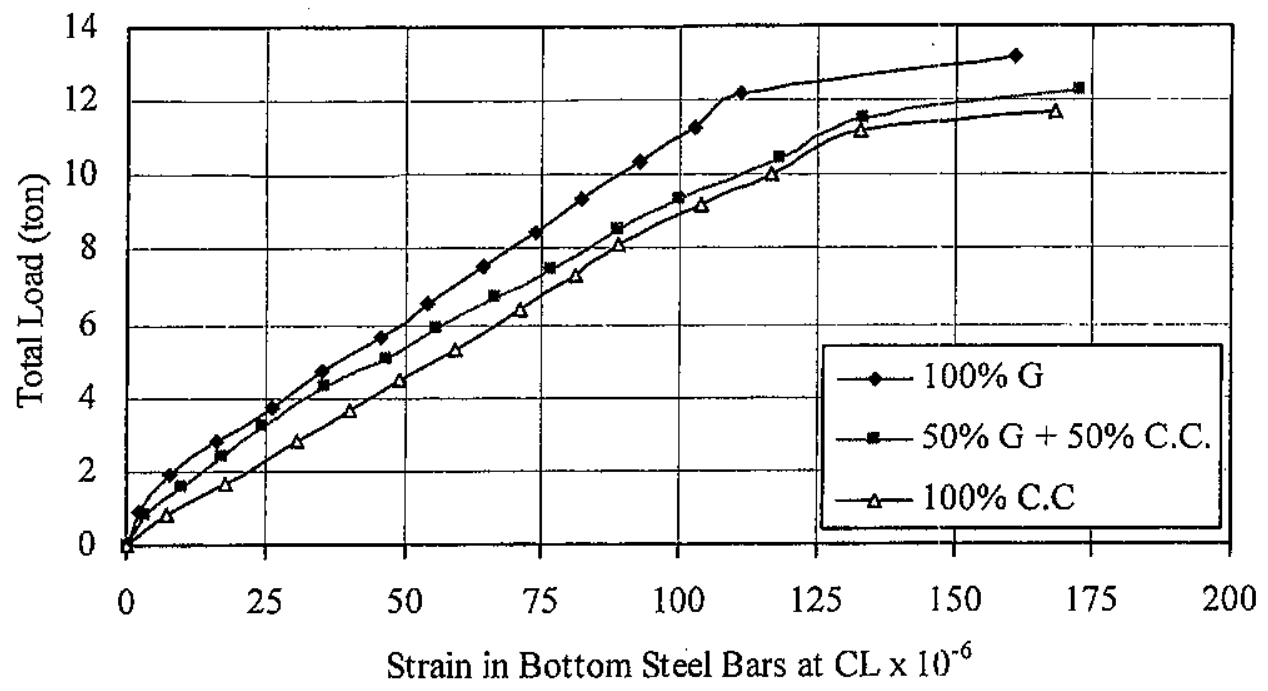

Fig. (9) Variation in the Strain of Bottom Steel Bars at the Centre Lines of Beams with Various Recycled Concrete Mixes under Shear loading

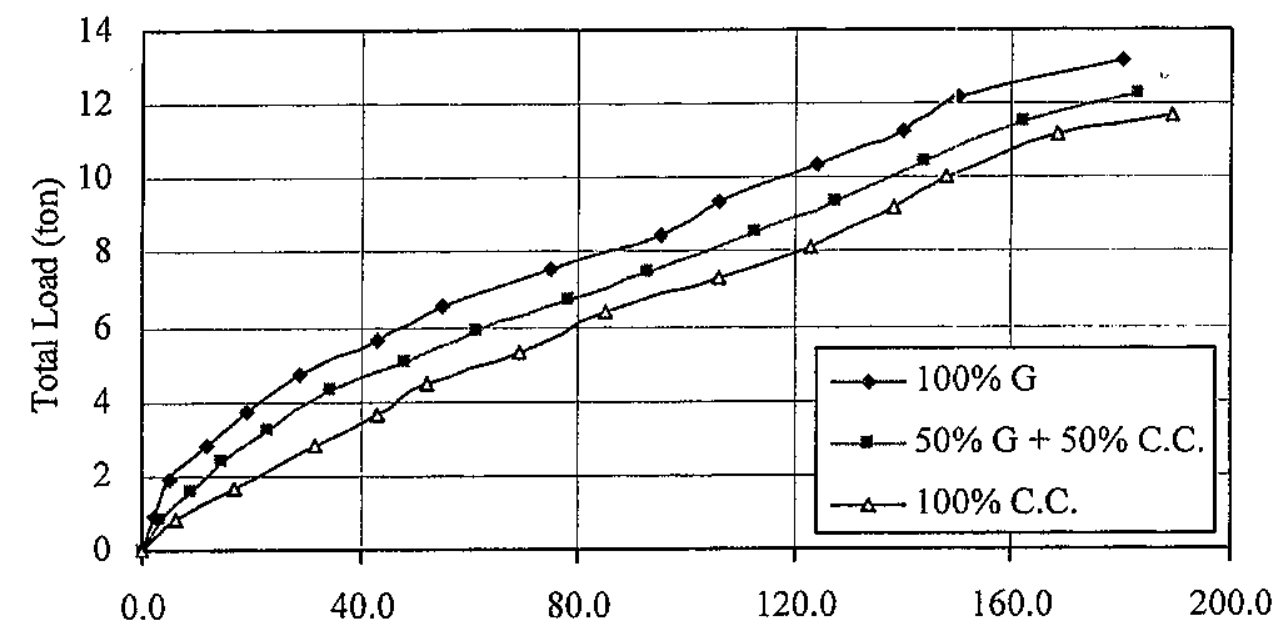

Strain in Bottom Steel Bars at End $\times 10^{-6}$

Fig. (10) Variation in the Strain of Bottom Steel Bars at the End of Various Beams with Various Recycled Concrete Mixes under Shear loading 
Mohamed H. Matthana, "Beahaviour of Reinforced Concrete Beams Made out of Recycled Concrete"

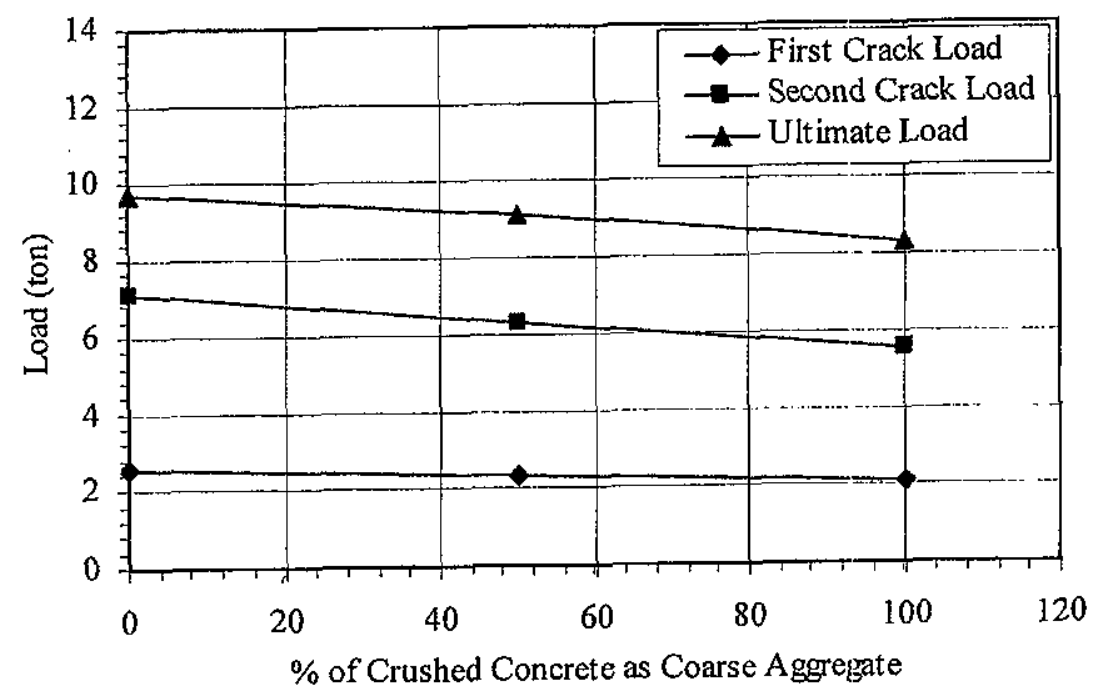

Fig. (11) Effect of the \% of Crushed Concrete as Coarse Aggregate on the Load Carrying Capacity of Beams under Flexural Loading

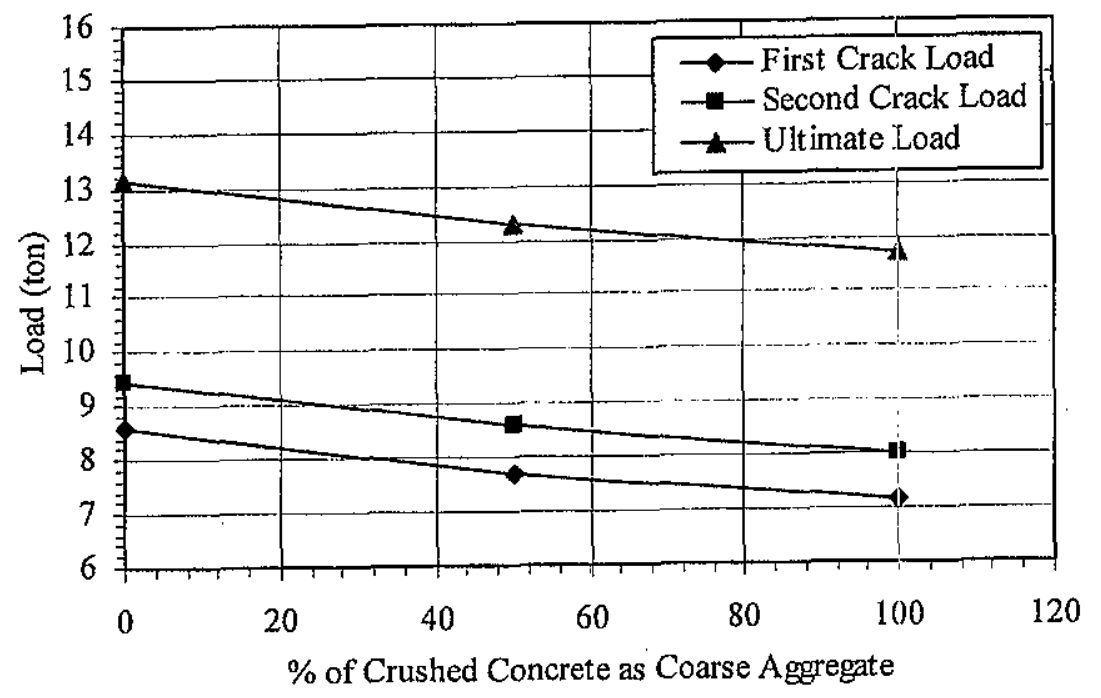

Fig. (12) Effect of the \% of Crushed Concrete as Coarse Aggregate on the Load Carrying Capacity of Beams under Shear Loading

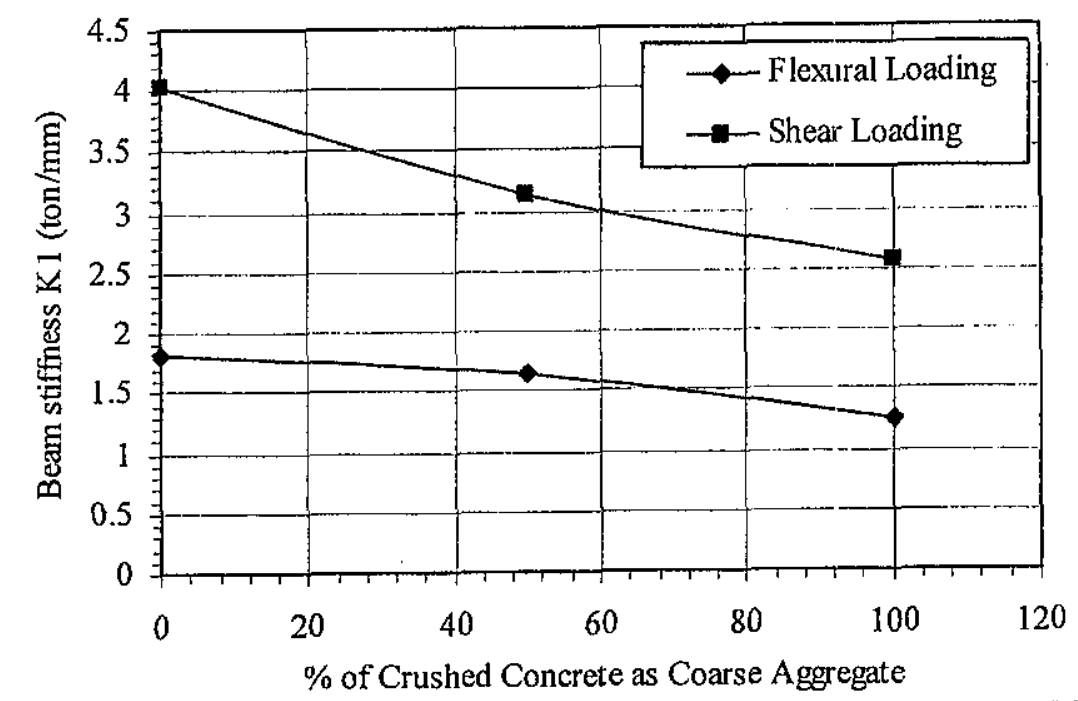

Fig. (13) Effect of the \% of Crushed Concrete as Coarse Aggregate on the Beam Stiffness; $K_{1}$ 
Mohamed H. Matthana, "Beahaviour of Reinforced Concrete Beams Made out of Recycled Concrete"

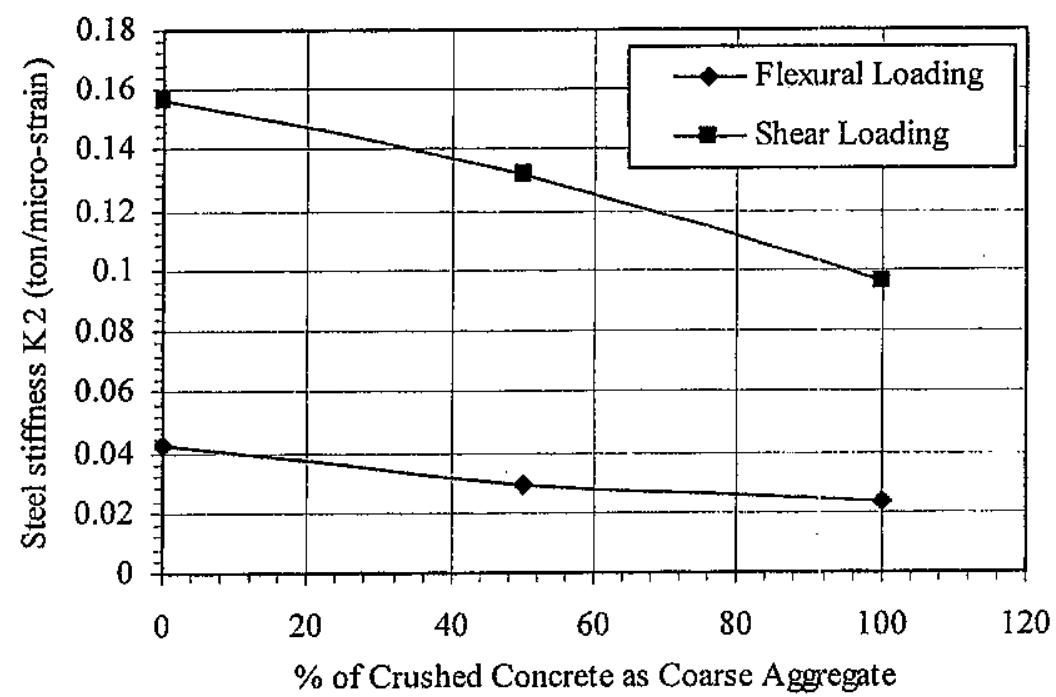

Fig. (14) Effect of the $\%$ of Crushed Concrete as Coarse Aggregate on the Steel Stiffness; $K_{2}$

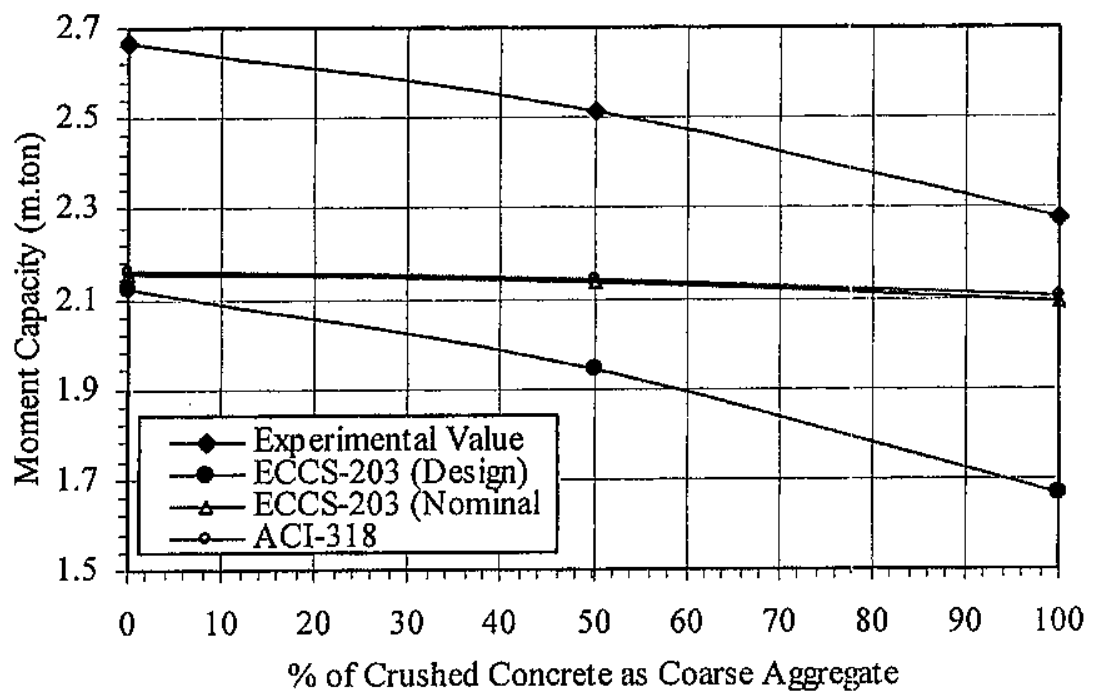

Fig. (15) Effect of \% of Crushed Concrete on the Moment Capacity of Beams Under Flexural Loading

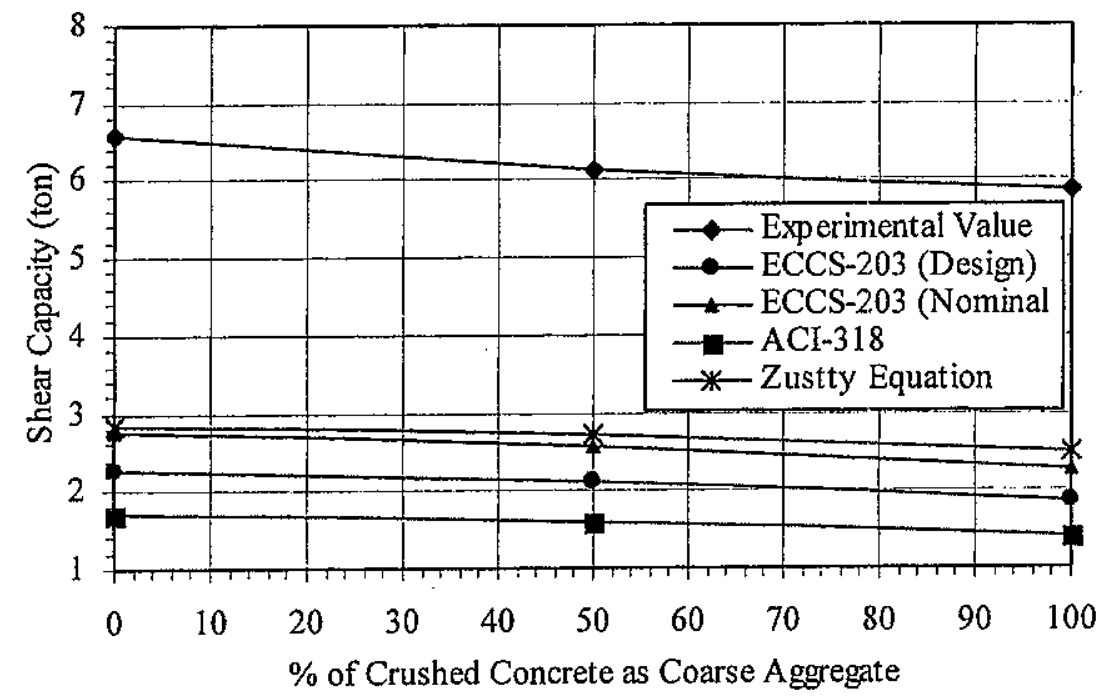

Fig. (16) Effect of \% of Crushed Concrete on the Shear Capacity of Beams Under Shear Loading 